REVIEW

\title{
Role of early post-settlement mortality in recruitment of benthic marine invertebrates
}

\author{
Heather L. Hunt*, Robert E. Scheibling \\ Department of Biology, Dalhousie University, Halifax, Nova Scotia, Canada B3H 4J1
}

\begin{abstract}
Newly settled invertebrates usually are subject to high rates of mortality (Type III survivorship). Therefore, knowledge of early post-settlement events is critical in determining if and when patterns of abundance and distribution of juveniles reflect settlement patterns. Causes of mortality of early juvenile invertebrates include delay of metamorphosis, biological disturbance, physical disturbance and hydrodynamics, physiological stress, predation, and competition. Predation is the best documented cause of early mortality, particularly for mobile species. Other possible causes which have not yet been investigated are developmental abnormalities, insufficient energy reserves, disease and parasitism. In most studies of sessile invertebrates, early post-settlement mortality did not obscure the relationship between recruit and settler abundance. This relationship appears to be more variable among mobile species for which migration also can modify the distribution of settlers. There is still insufficient data to support general conclusions about the conditions under which recruitment rate can be predicted from settlement rate. Studies have found evidence of the effects of both settlement and early post-settlement mortality on the distribution of some sessile species at small spatial scales, but mortality appears to have less influence at larger scales. Much of the present knowledge of the early postsettlement period has come from studies of barnacles and ascidians and more information is needed for other groups of benthic marine invertebrates, particularly mobile species. The relative importance of mortality during the early post-settlement period compared to other life history stages can only be determined in studies which examine several stages
\end{abstract}

KEY WORDS: Early post-settlement mortality - Settlement - Recruitment - Marine invertebrates . Density dependence Spatial scale - Disturbance Predation Physiological stress Competition

\section{INTRODUCTION}

Over the last 15 years, our understanding of recruitment variability of benthic marine invertebrates, and its role in population and community dynamics, has increased considerably. Variation in recruitment rate has been shown to affect competitive interactions (Sutherland \& Ortega 1986), predation (Fairweather 1988, Menge et al. 1994, Robles et al. 1995) and other community level processes on rocky shores (for review see Booth \& Brosnan 1995), and there is increasing evidence that adult population size is limited by recruitment for species on hard substrata in both intertidal (e.g. Connell 1985, Sutherland 1987, 1990, Menge \&

•E-mail: hlhunt@is2.dal.ca
Farrell 1989, Raimondi 1990, Menge 1991) and subtidal habitats (e.g. Hughes 1990, Karlson \& Levitan 1990). Consequently, recent models of population dynamics (Roughgarden et al. 1985, Roughgarden \& Iwasa 1986, Alexander \& Roughgarden 1996) and community organization on rocky bottoms (Menge \& Sutherland 1987) incorporate recruitment variability as a limiting factor. Recruitment limitation has received less attention from researchers studying soft bottom communities (but see Peterson \& Summerson 1992, Peterson et al. 1996, Butler \& Herrnkind 1997). A recent review by Ólafsson et al. (1994) concluded that larval supply is generally not limiting, and therefore is probably not a major determinant of patterns of species distribution and abundance in sedimentary habitats. However, interactions between adults and 
settlers/recruits have been shown to affect recruitment rate (Peterson 1982, Peterson \& Black 1993, Ólafsson et al. 1994, Thrush et al. 1996) and may limit the density of infauna (Thorson 1966, Woodin 1976, Peterson 1979).

Many factors can influence the intensity and variability of recruitment of benthic marine invertebrates The abundance of larvae in the water column is influenced by adult reproductive cycles, larval mortality (Roughgarden et al. 1988), and settlement rate itself (Gainus et al. 1985). Physical factors which affect dispersal of larvae include wind (Bertness et al. 1996, Morgan et al. 1996), linear oceanographic features (for review see Kingsford 1990), upwelling (Farrell et al. 1991, Roughgarden et al. 1991. Wing et al. 1995), cold water plumes (Ebert \& Russell 1988), water residence time in estuaries (Gaines \& Bertness 1992), and vertical distribution of larvae in the water column (Grosberg 1982, Le Fèvre \& Bourget 1991, Miron et al. 1995). Settlement onto the substratum occurs once the larvae reach. a suitable habitat. Settlement is a process that may include reversible or irreversible contact with the substratum, exploratory behaviour, orientation, and metamorphosis (which may occur before, during, or after contact with the substratum) (Pawlik 1992) At this time, the pattern of larval supply may be modified by larval response to various abiotic and biotic cues on the substratum, including surface texture or chemistry. conspecifics, and the presence or absence of other macrobenthic species or microbial films (reviewed by Pawlik 1992). Hydrodynamic conditions may determine the scale at which active selection of a substratum occurs (Butman 1987).

In this review, we will focus on the period between settlement and recruitment. Monitoring newly settled individuals is difficult due to their small size and because sampling must be frequent enough to avoid confounding patterns of settlement with patterns modified by early post-settlement mortality. For convenience, most researchers measure recruitment days to months after settlement (e.g. Shanks \& Wright 1987. Ebert \& Russell 1988, Gaines \& Bertness 1992, Ebert et al. 1994, Wing et al. 1995). Knowledge of early postsettlement events is critical in determining if and when recruitment patterns reflect settlement patterns. In situations where early post-settlement events substantially alter the abundance of recruits, they may regulate population size and adult distribution, and reduce the importance of interactions between adults. Gosselin \& Qian (1997) recently reviewed 30 studies of rates of mortality of juvenile benthic invertebrates. They discussed causes of early post-settlement mortality, methods of quantifying mortality rates, and the influence of juvenile mortality on age at maturity. In our review, we strive for a more comprehensive exam- ination of the major functional groups of benthic marine invertebrates, including sessile species on hard substrates, mobile epifauna, and infauna in sedimentary habitats. We begin by discussing problems with the definition of recruitment and the early post-settlement period. We then review the rates and patterns of early post-settlement mortality reported in the literature and discuss factors which affect the survival of newly settled and early juvenile individuals. Finally, we address the influence of mortality of recent settlers on patterns of abundance and distribution of recruits.

\section{EARLY POST-SETTLEMENT PERIOD}

Recruitment is an operational term rather than a biological event, and consequently, has been defined in many different ways. Definitions of recruitment of benthic marine invertebrates include (Booth \& Brosnan 1995) (1) presence of juveniles after a specified time interval, (2) attainment of a specified size, (3) survival through a period of high early mortality, (4) survival to a size when the settlers become vulnerable to predators, and (5) retention on a particular sieve mesh size (in sott bottom studies, Butman 1987). Differences in the time interval to recruitment are inevitable due to differences in the life histories and lifespans of organisms. For example, it might not be reasonable to consider a barnacle which reaches maturity in $6 \mathrm{wk}$ and a slow-growing coral which may live more than 20 yr to be recruits after the same time interval. Also, the time interval before a settler can be censused by an observer (recruitment sensu Keaugh \& Downes 1982) will differ among species because of variability in initial size and growth rate (Rumrill 1989) and also because of differences in our ability to sample different habitats.

Booth \& Brosnan (1995) have suggested that survival through high (usually Type III, sensu Deevey 1947) mortality in the first few days to weeks after settlement may be a biologically meaningful definition of recruitment. This suggestion is reasonable, considering that early mortality often follows this pattern (see Table 1 and the following section). However, survival curves of early juveniles of some species exhibit other patterns, and this type of information is not available for many species. A combination of criteria may be necessary to define the early post-settlement stage for a particular species. For mobile epibenthic species, differences in behaviour and habitat between early juveniles and older juveniles and adults may help define the time at which recruitment occurs. Because recruitment is not a distinct biological event like settlement, definitions will continue to differ from species to species. However, efforts should be made to harmonize definitions 
of recruitment (or to redefine the term, see 'Conclusions and directions for future research') and to use biologically meaningful criteria when defining the early post-settlement period.

Comparisons of studies are complicated by differences in sampling interval. Variation in sampling interval has been shown to affect estimates of recruitment and (or) early post-settlement mortality of oysters (Michener \& Kenny 1991) and barnacles (Minchinton \& Scheibling 1993b, Gosselin \& Qian 1996). Minchinton \& Scheibling (1993b) found that estimates of recruitment and early post-settlement mortality of the barnacle Semibalanus balanoides decreased significantly when the sampling interval was changed from 1.3 to $2.1 \mathrm{~d}$, and continued to decrease exponentially with increasing sampling interval. Sampling interval also altered comparisons of early post-settlement mortality rate between intertidal zones. These results suggest that comparisons of studies with different sampling regimes should be made cautiously.

\section{RATES AND PATTERNS OF EARLY MORTALITY}

In the field, monitoring mortality immediately after settlement is difficult, if not impossible, for many species. However, without knowledge of events shortly after settlement, post-settlement mortality can be underestimated and settlement patterns can be confounded by patterns produced by or modified by mortality. Mortality rate in the field during the first few hours or days after settlement is known for only 2 groups of benthic marine invertebrates: barnacles and ascidians. Survival rates of barnacle cyprids during the first 24 to 48 h range from 22 to $87 \%$ (Balanus glandula, Gosselin \& Qian 1996; Semibalanus balanoides Connell 1961, Kendall et al. 1985, Bergeron \& Bourget 1986; Chthamalus fragilis, Young 1991), and mortality risk does not necessarily decline after metamorphosis (S. balanoides, Wethey 1986). In studies of colonial. ascidians, 50 to $>70 \%$ of settlers survive the first $24 \mathrm{~h}$ (Diplosoma similis, Stoner 1990; Podoclavella moluccensis, Davis 1987). Mobile species probably also experience elevated mortality immediately after settlement, but survival rates have not been measured. Indirect evidence of high early mortality is provided by Eggleston \& Armstrong's (1995) study of Dungeness crabs (Cancer magister): settlement patterns and density of first benthic instar crabs were decoupled in less than 48 h. The first day after settlement may be a critical period for many benthic invertebrates. Ciosselin \& Qian (1996) found that mortality of the barnacle Balanus glandula was 1.5 to 6 times higher during the first day after settlement than during the second day. Indeed, for 2 of the 3 cohorts monitored, mortality dur- ing the first day after settlement was almost as high as total mortality during the subsequent $44 \mathrm{~d}$

Mortality in the days to weeks after settlement is generally high (Table 1; Gosselin \& Qian 1997). In 2 studies of tropical colonial ascidians (Trididemnum solidum, van Duyl et al. 1981; Diplosoma similis, Stoner 1990), all visible settlers disappeared during the 1 to 4 mo monitoring period. However, neither study was able to follow the fate of individuals which settled in crevices or other protected microhabitats. Small individuals of some species have high survival rates. For example, $63 \%$ of settlers of the colonial ascidian Podoclavella moluccensis survived 1 mo (Davis 1988a), and 65 to $80 \%$ of settlers of the barnacle Chthamalus anisopoma survived to reach maturity at $6 \mathrm{wk}$ of age (Raimondi 1990)

Survival curves of new settlers (Table 1) are often Type III: survival rate decreases rapidly and then levels off (Deevey 1947). Gosselin \& Qian (1997) pooled data from 30 studies of juvenile benthic invertebrates to produce a general survivorship curve and found an interspecific trend of exponentially decreasing survivorship during the first days to weeks after settlement. Decreases in mortality rate of early juveniles with time also have been noted in studies which do not present survival curves (Keough 1986, Keough \& Chernoff 1987, Günther 1992). A Type Ill pattern of mortality can even occur in the benign conditions of the laboratory (e.g Roegner 1991). However, newly settled invertebrates also exhibit other patterns of survivorship. Hurlbut (1991a) found that mortality rate of a number of sessile species on subtidal panels was higher in the second week after settlement than in the first week, and suggested that the increase in mortality was due to density dependent predation. Early mortality may also follow a Type II survivorship curve in which mortality is independent of age (Table 1). In some cases, however, the reported survival curve may represent only a portion of the overall curve. High mortality may have occurred in the first hours to days after settlement before survival was monitored, or mortality rate may level of over a longer time interval than the period of study. However, Gaines \& Roughgarden (1985) found that weekly survivorship of the barnacle Balanus glandula was independent of age for the entire first year of life, and that survival rate of settlers monitored from the first low tide after settlement did not differ from that of older barnacles.

\section{VARIABILITY IN EARLY POST-SETTLEMENT MORTALITY}

Studies examining variability in early post-settlement mortality have found variation at several spatial 

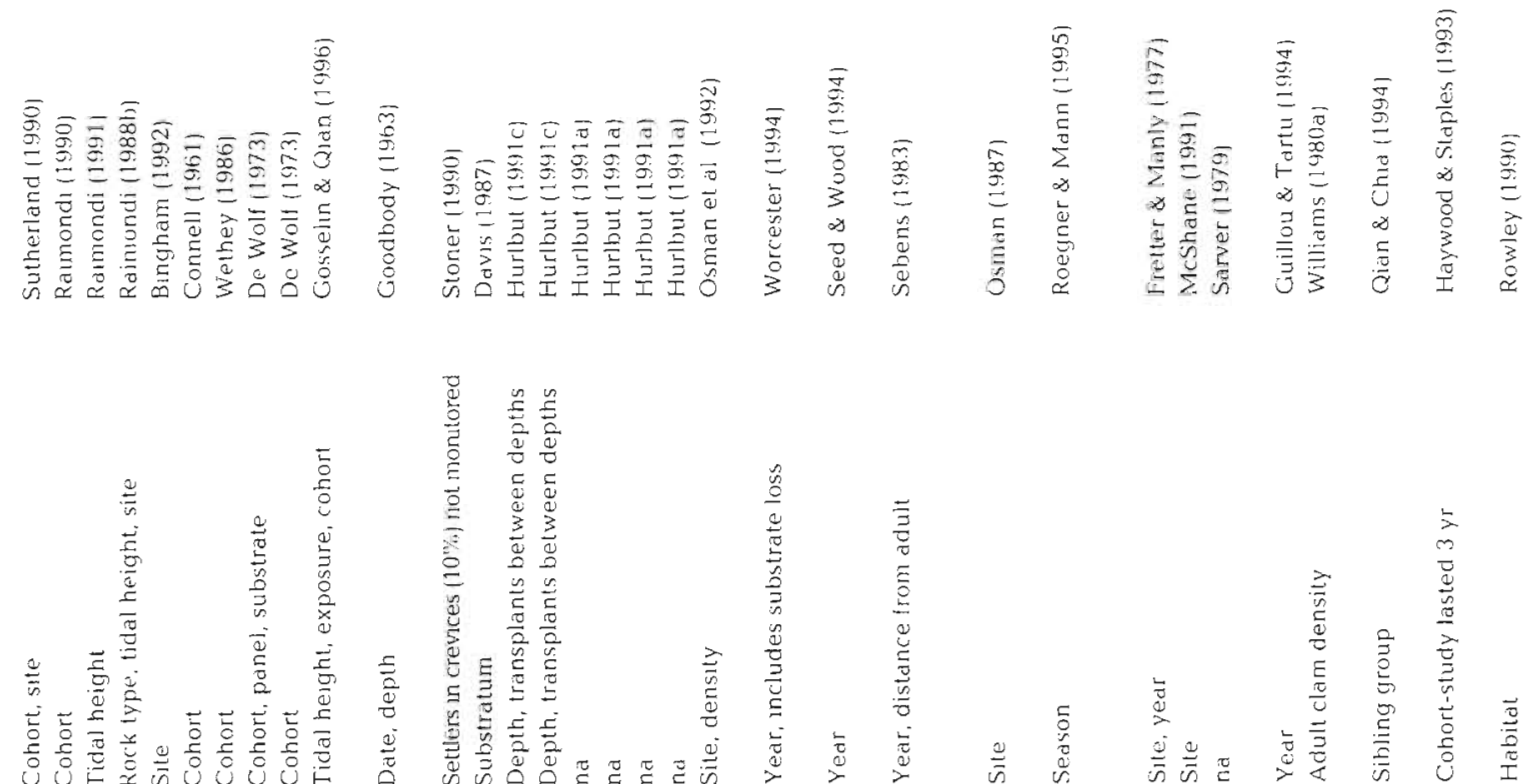

$\stackrel{0}{0}$

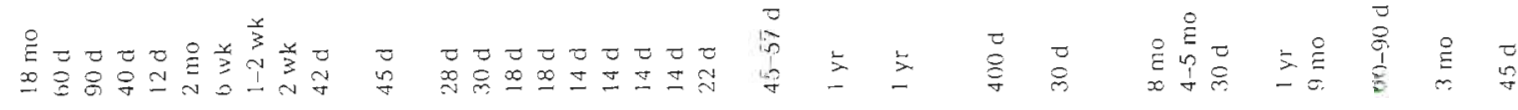

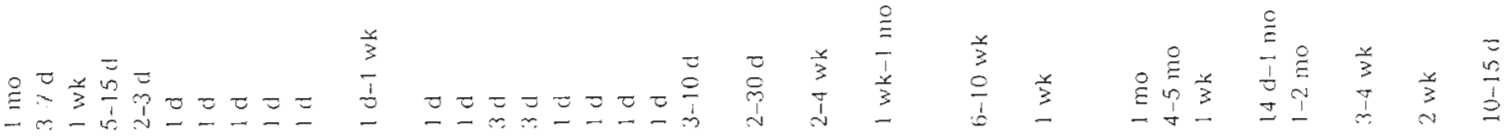


and temporal scales. Spatial variability in mortality of barnacle settlers has been detected at scales of metres to kilometres (Meadows 1969, De Wolf 1973, Caffey 1982, 1985, Wethey 1986, Bingham 1992). However, in some of these studies, estimates of post-settlement mortality were based on counts of 1 to 2 mo old juveniles (Meadows 1969, Caffey 1982, 1985), and consequently excluded mortality occurring shortly after settlement. Spatial variability in early post-settlement mortality at scales of kilometres also has been reported for the sea hare Aplysia juliana (Sarver 1979). In contrast, Keesing et al. (1996) found that early post-settlement mortality of the sea star Acanthaster planci did not vary significantly among habitats (front reef slope, reef flat, back reef lagoon) or sites within habitats.

A number of studies which have monitored barnacle cohorts have detected differences in mortality rate between cohorts settling within 1 or $2 \mathrm{~d}$ of one another (Connell 1961, De Wolf 1973, Wethey 1986, Kendall \& Bedford 1987, Raimondi 1990, Sutherland 1990). Wethey (1986) suggested that temporal dispersion of settlement (i.e. an extended settlement season) is advantageous when there is no temporal trend in mortality, as was the case in his study of Semibalanus balanoides. In contrast, Raimondi (1990) and Connell (1961) found that earlier cohorts of barnacles (Chthamalus anisopoma and $S$. balanoides respectively) had higher survivorship. They suggested that early settlers fill up the most suitable settlement sites (pits or other concavities), leaving later settlers vulnerable to high temperatures and desiccation or gales. On a rocky shore in England, Bowman (1986) found that limpets (Patella vulgata) which settled earlier in the fall had a lower mortality rate than those which settled later. She hypothesized that limpets suffer high mortality if they are not large enough to emigrate from their settlement microhabitat before winter. Variation in mortality amang cohorts (determined from size frequency analysis) also has been detected for 2 species of prawns in Australia, Penaeus merguiensis (Haywood \& Staples 1993) and Penaeus esculentus (O'Brien 1994a). For both species, cohorts which entered estuaries in summer (the wet season) suffered higher mortality than prawns settling in other seasons.

Intensity and variability of early post-settlement mortality can differ among species which are monitored simultaneously. Bingham (1992) transplanted recruits of mangrove epifaunal species to different channels in a mangrove island and found that mortality of barnacle (Balanus eburneus) recruits was greater and more variable than that of ascidians (Symplegma viride, Diplosoma glandulosum, and Botryllus planus) or polychaetes (Hydroides sp.). Keesing et al. (1996) transplanted 1 mo old sea stars from the laboratory to the field, and found that the mortality rate of Acan- thaster planci was 5 times higher than that of the larger Nardoa novaecaladoniae. Hurlbut (1991a) found that the intensity, age dependence, and density dependence of early post-settlement mortality differed among species in a sessile community on subtidal panels. Such variability in early mortality among species suggests that recruitment patterns measured for one species will not predict patterns for other members of the community, an assumption of some models which strive to predict the effect of recruitment strength on community arganization (e.g. Menge \& Sutherland 1987)

\section{CALSES OF EARLY POST-SETTLEMENT MORTALITY}

\section{Delay of metamorphosis}

For many invertebrate species, delay of metamorphosis eventually results in a decrease in larval condition, substratum selectivity, or ability to metamorphose (for review see Pechenik 1990). Extended larval life also has the potential to affect juvenile survival and condition in some species (Table 2). In the laboratory, delayed metamorphosis reduced survival of juveniles of the polychaete Capitella sp. I (Pechenik \& Cerulli 1991) and appeared to reduce stress tolerance of the sand dollars Dendraster excentricus and Echinarachinus parma (Highsmith \& Emlet 1986). Prolonged larval life decreased survival of juveniles of the nudibranch Phestilla sibogae that were raised as lecithotrophic larvae but not of those raised as facultatively planktotrophic larvae (Miller 1993). Unlike planktotrophic larvae, lecithotrophic larvae experience depletion of stored nutrients during delay of metamorphosis, resulting in decreased size at metamorphosis (Miller 1993). An extended competency period had little effect on survival of juveniles of the barnacle Balanus amphitrite (Pechenik et al. 1993) and no effect on survivorship of the gastropod Crepidula fornicata (Pechenik \& Eyster 1989) To date, there is only indirect evidence of delay of metamorphosis in the field (for review see Pechenik 1990). The consequences of prolonged larval life for early post-settlement mortality will depend on how frequently delayed metamorphosis occurs and on how it affects juvenile survival in nature.

\section{Biological disturbance}

Accidental ingestion or 'bulldozing' by grazers such as limpets, littorinids and sea urchins has been well documented as a cause of early post-settlement mortality and reduced recruitment of barnacles, limpets, 
ascidians, and corals (Table 2). Vulnerability to disturbance by grazers may decrease with size (age) (Miller \& Carefoot 1989, Safriel et al. 1994) and substratum heterogeneity (Sammarco 1980, Miller \& Carefoot 1.989, but see Denley \& Underwood 1979). Grazers can also influence the abundance of sessile invertebrates indirectly through their effects on algal abundance. For example, Petraitis (1990) attributed the negative effect of Littorina httorea on mussel recruitment to the gastropod's reduction of the algae on which mussels settle. Low densities of grazers may positively affect the abundance (Petraitis 1983), survival (Creese 1982), or condition (Sammarco 1980) of recruits, presumably due to reduction of the abundance of algae and other competitors which either prevent settlement or overgrow recently settled individuals.

On hard substrata, biological disturbance by organisms other than grazers has received less attention. Davis (1988b) found that crabs kill recruits of the colonial ascidian Podoclavella moluccensis by trampling them with their sharp dactyls. In the intertidal zone, fucoid algae have both positive and negative effects on barnacle recruitment (Dayton 1971. Hawkins 1983 and references therein). Fucoids have been hypothesized to decrease settlement of barnacles by a whiplash effect or by altering water flow, and to increase (by whiplash) or decrease (by reduced desiccation) early post-settlement mortality (for discussion see Grant 1977. Hawkins 1983). In the only study to directly measure canopy effects on barnacle mortality, Grant (1977) found that an artificial algal canopy (strips of inner tube rubber) decreased post-settlement survival of Semibalanus balanoides. Heavy cover of Fucus is also associated with decreased limpet (Patella vulgata) recruitment (Lewis \& Bowman 1975).

Adult infauna in soft-bottom communities can cause mortality of newly settled macrofauna by bioturbation of the sediments (but see McCann \& Levin 1989). Peterson (1977) found that removal of the ghost shrimp Callianassa californiensis, a deposit feeder, increased recruitment of the clam Sanguinolaria nuttallii. He suggested that burial and direct consumption of juvenile clams by $C$. californiensis were the most likely mechanisms for the negative effect of the shrimp on clam recruitment. Brenchley (1981) demonstrated that densities of spionid polychaetes (Rhynchospio arenicola) and tanaid crustaceans (Leptochelia dubia), particularly small individuals, were decreased by addition of macroinfaunal (the lug worm Abarenicola pacifica and the mud shrimps Ugopebia pugettensis and C.californiensis) or macroepifaunal (the sand dollar Dendraster excentricus) burrowers. Addition of sediment also reduced densities, suggesting that physical events were important in the interaction between bioturbators and recruits (Brenchley 1981). In the laboratory, Ahn et al. (1993) found that the clam Gemma gemma reduced survival of recent settlers of another clam (Mercenaria mercenaria) in muddy sand but not in sand, and suggested that the increased mortality in muddy sand was due to burial and exposure to pore water metabolites from sediment reworking by $G$. gemma. Interference with feeding can also cause early post-settlement mortality. Cummings et al. (1996) found that the tube building spionid polychaete Boccardia syrtis decreased survival of early juvenile clams (Macoma litiana) in the laboratory. The polychaetes did not ingest the clams but caused them to retract their siphons, and thus interrupted feeding Meiofaunal burrowers also can cause mortality of newly settled macrofauna. In the field, Watzin (1986) showed that meiofauna other than turbellarians (primarily nematodes and copepods) decreased the survivorship of recently settied bivalves, most likely by sediment destabilization. However, Zobrist \& Coull (1994) found that meiofaunal bioturbators (copepods, nematodes, foraminifera) did not affect the survival of newly settled bivalves ( $M$. mercenaria) and polychaetes (Streblospio benedicti) in the laboratory. They suggested that meiofauna (with the possible exception of predaceous turbellarians) do not play a large role in early post-settlement mortality of macrofaunal species.

\section{Physical disturbance and hydrodynamics}

Physical disturbance has received relatively little attention as a cause of mortality for newly settled invertebrates. Connell (1961) found that mortality of both cyprids and newly metamorphosed barnacles (Semibalanus balanoides) increased during gales, when mortality was greater at convexities on the substratum than in more protected microhabitats such as crevices or depressions. Eckman (1987) determined that current speed affected post-settlement survival of one species of bivalve (Argopecten irradians) but not another (Anomia simplex) in eelgrass meadows. Survival of $A$. irradians was lower in regions with faster currents, possibly because recruits were dislodged (Eckman 1987). Survival of abalone (Haliotis iris) settlers transplanted to the field was greater in deep than shallow habitats, possibly due to reduced dislodgment by wave action (McShane \& Naylor 1995)

\section{Physiological stress}

Newly settled invertebrates are generally more susceptible than older juveniles and adults to physiological stress (Hatton 1938, Foster 1971, Branch 1975 , Olson 1983, Dungan 1985, Baker \& Mann 1992, Gos- 
Table 2. Summary of studies examinng effects of various factors on non-predatory early post-settlement mortality in benthic marine invertebrates. Recr: recruitment rather than mortality was measured in determining effect on survival; obs: observations

\begin{tabular}{|c|c|c|c|c|}
\hline Factor & Species & Method & Effect & Source \\
\hline \multicolumn{5}{|c|}{ Delayed metamorphosis } \\
\hline \multicolumn{5}{|c|}{ Echinoldea } \\
\hline & Dendraster excentricus & Lab expt & Yes & Highsmuth \& Emlet (1986) \\
\hline \multirow{2}{*}{\multicolumn{5}{|c|}{ Gastropoda }} \\
\hline & & & & \\
\hline & Crepidula fornicata & Lab expt & No & Pechenlk \& Evster (1989) \\
\hline & Phestilla sibogae & Lab expt & $\begin{array}{l}\text { Dependent on larval } \\
\text { life history }\end{array}$ & Miller (1993) \\
\hline \multicolumn{5}{|c|}{ Polychaeta } \\
\hline & Capitellasp. I & Lab expt & Yes & Pechenik \& Cerulli (1991) \\
\hline & \multicolumn{4}{|l|}{ Barnacle } \\
\hline \multicolumn{5}{|c|}{ Biological disturbance } \\
\hline \multicolumn{5}{|c|}{ Grazers } \\
\hline \multirow{2}{*}{\multicolumn{5}{|c|}{ Cirripedia }} \\
\hline & & & & \\
\hline & Tesseropora rosea & Field expt & Yes & Denley \& Underwood (1979) \\
\hline & \multirow[t]{6}{*}{ Semibalanus balanoides } & Lab expt & Yes & Miller \& Carefoot (1989) \\
\hline & & Field expt (recr) & Yes & Hawkins (1983) \\
\hline & & Fleld expt (recr) & Yes & Connell (1961) \\
\hline & & Field expt (recr) & Yes & Menge (1976) \\
\hline & & Field obs & Yes & Hatton (1938) \\
\hline & & Field expt (recr) & Yes & Petraitis (1983) \\
\hline & Balanus amphitrite & Field expt & Yes & Satriel et al. (1994) \\
\hline & Chthamalus fissus & Field obs & No & Sutherland \& Ortega (1986) \\
\hline & \multirow[t]{2}{*}{ Balanus glandula } & Field obs & Yes & Stımson $(1970)$ \\
\hline & & Field expt (recr) & Yes & Dayton (1971) \\
\hline & $\begin{array}{l}\text { Not identified to sp. } \\
\text { Monoplacophora }\end{array}$ & Field expt (recr) & Yes & Turner \& Todd (1991) \\
\hline & Patella latistrigata & Field expt & Density dependent & Creese (1982) \\
\hline & Ascidiacea & & & \\
\hline & Corella inflata & Lab expt & Yes & Young \& Chia (1984) \\
\hline & Boltenia villosa & Lab expt & Yes & Young \& Chia (1984) \\
\hline & Styela gibbsii & Lab expt & Yes & Young \& Chia (1984) \\
\hline & Not identified to sp. & Field expt (recr) & Yes & Turner \& Todd (1991) \\
\hline & Bryozoa & & & \\
\hline & Ctenostome & Field expt (recr) & Yes & Turner \& Todd (1991) \\
\hline & Cheilostome & Field expt (recr) & Yes & Turner \& Todd (1991) \\
\hline & Hydroida & Field expt (recr) & Yes & Turner \& Todd (1991) \\
\hline & Polychaeta & Field expt (recr) & Yes & Turner \& Todd (1991) \\
\hline \multicolumn{5}{|c|}{ Urchins } \\
\hline & \multicolumn{4}{|l|}{ Anthozod } \\
\hline & Favia fragum & Field expt & Yes & Sammarco $(1980)$ \\
\hline & Agaricia spp. & Field expt & Yes & Sammarco $(1980)$ \\
\hline & Porites spp. & Field expt & Yes & Sammarco $(1980)$ \\
\hline & \multicolumn{4}{|l|}{ Echinoidea } \\
\hline & \multirow{2}{*}{\multicolumn{4}{|c|}{ Gastropoda }} \\
\hline & & & & \\
\hline & Turbo intercostalis & Field expt (recr) & No & Prince (1995) \\
\hline & Cypraeea caputserpentis & Fleld expt (recr) & No & Prince (1995) \\
\hline & Thais orbita & Field expt (recr) & No & Prince (1995) \\
\hline & Siphonaria zelandica & Field expt (recr) & Yes & Prince (1995) \\
\hline \multicolumn{2}{|l|}{ Crab } & & & \\
\hline & Podoclavella moluccensis & Field expt & Yes & Davis (1.988b) \\
\hline \multirow{2}{*}{\multicolumn{5}{|c|}{ Algae }} \\
\hline & & & & \\
\hline & Sembalanus balanoides & Field expt & Yes & Grant (1977) \\
\hline $\begin{array}{r}\text { Adult } \\
\mathrm{MaCl}\end{array}$ & & & & \\
\hline & Polychaeta & & & \\
\hline & Streblospio benedicti & Field expt & No & McCann \& Levin (1989) \\
\hline & Rhynchospio arenicola & Field and lab expts & Yes & Brenchley (1981) \\
\hline
\end{tabular}


Table 2 (continued)

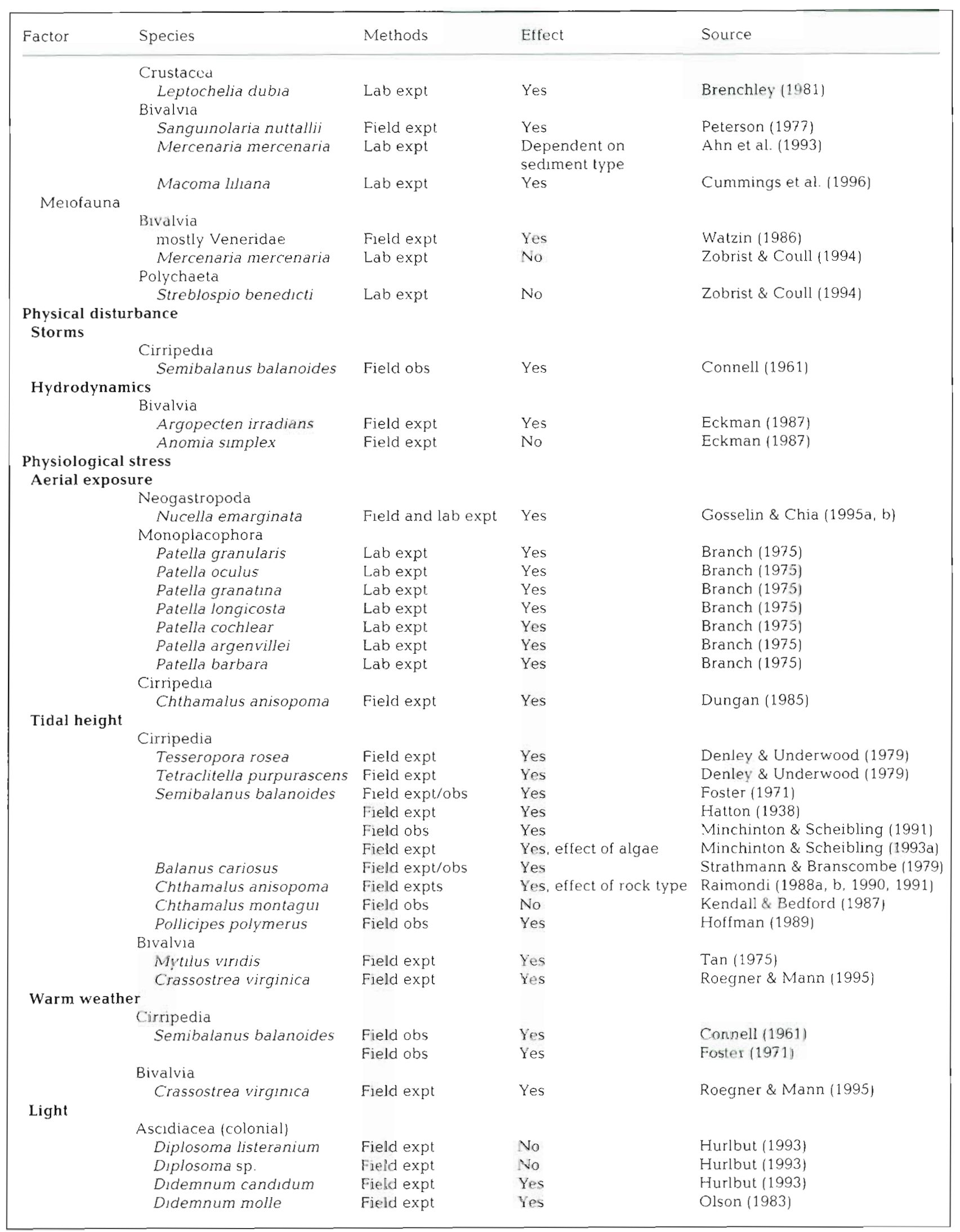


Table 2 (continued)

\begin{tabular}{|c|c|c|c|c|}
\hline Factor & Species & Methods & Effect & Source \\
\hline \multicolumn{5}{|c|}{ Hypoxia/anoxia } \\
\hline \multicolumn{5}{|c|}{ Bivalvia } \\
\hline & Crassostrea virgmica & Lab expt & Yes & Baker \& Mann (1992) \\
\hline \multicolumn{5}{|c|}{ Siltation } \\
\hline \multicolumn{5}{|c|}{ Ascidiacea } \\
\hline & Corella inflata & Field expt & Yes & Young \& Chia (1984) \\
\hline & Ascidia callosa & Field expt & Yes & Young \& Chia $\{1984\}$ \\
\hline & Ascidia paratropa & Field expt & Yes & Young \& Chia (1984) \\
\hline & Pyura haustor & Field expt & Yes & Young \& Chia (1984) \\
\hline & Boltenia villosa & Field expt & Yes & Young \& Chia $\{1984\}$ \\
\hline & Styela gibbsii & Field expt & Yes & Young \& Chia (1984) \\
\hline & Diplosoma listeranium & Field expt & Yes & Hurlbut (1993) \\
\hline & Diplosoma sp. & Field expt & Yes & Hurlbut (1993) \\
\hline \multicolumn{5}{|c|}{ Salinity and temperature } \\
\hline \multicolumn{5}{|c|}{ Decapoda } \\
\hline & Menippe adina & Lab expt & Yes & Brown \& Bert (1993) \\
\hline \multirow{2}{*}{\multicolumn{2}{|c|}{ Menippe mercenaria }} & Lab expt & Yes & Brown \& Bert (1993) \\
\hline & & Lab expt & Yes & Brown et al. (1992) \\
\hline \multirow{2}{*}{\multicolumn{2}{|c|}{ Penaeus esculentus }} & Lab expt & Yes & O'Brien (1994a) \\
\hline & & Field obs & No (temperature) & O'Brien (1994b) \\
\hline \multirow{2}{*}{\multicolumn{2}{|c|}{ Penaeus merguensis }} & Lab expt & Yes & Staples \& Heales (1991) \\
\hline & & Field obs & Yes (temperature) & Haywood \& Staples (1993) \\
\hline \multicolumn{5}{|c|}{ Amphipoda } \\
\hline & Corophium volutator & Lab expt & Yes & Mills \& Fish (1980) \\
\hline & Corophium arenarium & Lab expt & Yes & Mills \& Fish (1980) \\
\hline & Asteroidea & & & \\
\hline & Patiriella pseudoexigua & Lab expt & Yes & Chen \& Chen (1993) \\
\hline & Demospongiae & & & \\
\hline & $\begin{array}{l}\text { Haliclona tubifera, } \\
\text { Halichondra magniconulosa }\end{array}$ & Lab expt & $\begin{array}{l}\text { Yes (only temperature } \\
\text { tested) }\end{array}$ & Maldonaldo \& Young (1996) \\
\hline \multicolumn{5}{|c|}{ Dinoflagellate bloom } \\
\hline \multicolumn{5}{|c|}{ Bivalvia } \\
\hline & Argopecten irradians & Field obs & Yes & Summerson \& Peterson (1990) \\
\hline \multicolumn{5}{|c|}{ Competition/overgrowth } \\
\hline \multicolumn{5}{|c|}{ Cirripedia } \\
\hline & Tetraclitella purpurascens & Field expt & Yes & Denley \& Underwood (1979) \\
\hline & Tesseropora rosea & Field expt & Yes & Denley \& Underwood (1979) \\
\hline \multicolumn{5}{|c|}{ Anthozoa } \\
\hline & Pocillopora damícornis & Field and lab expts & Yes & Harriott (1983) \\
\hline & Capnella gaboensis & Lab expt & Yes & Farrant $(1987)$ \\
\hline \multicolumn{5}{|c|}{ Octocorallia } \\
\hline & Alcyonum siderium & Field obs & Yes & Sebens (1983) \\
\hline \multicolumn{5}{|c|}{ Ascidiacea } \\
\hline & Corella inflata & Field expt & Depth dependent & Young \& Chia (1984) \\
\hline & Ascidia callosa & Field expt & Depth dependent & Young \& Chia (1984) \\
\hline & Ascidia paratropa & Field expt & Yes & Young \& Chia $(1984)$ \\
\hline & Pyura haustor & Freld expt & Depth dependent & Young \& Chia (1984) \\
\hline & Boltenia villosa & Freld expt & Depth dependent & Young \& Chia (1984) \\
\hline & Styela gibbsil & Field expt & Yes & Young \& Chia (1984) \\
\hline & Podoclavella cylindrica & Field obs & Yes & Davis (1987) \\
\hline & Bryozoa & & & \\
\hline & Bugula pacifica & Field obs & Yes & Young \& Chia (1981) \\
\hline & Fouling community & Field expt & Yes & Osman \& Whitlach (1995b) \\
\hline & Bivalvia & & & \\
\hline & Crassostrea virginica & Field and lab expts & Yes & Osman et al. (1989) \\
\hline & & Field and lab expts & Yes & Zajac et al. (1989) \\
\hline & Tapes japonica & Field expt & No & Williams (1980a) \\
\hline & Monoplacophora & & & \\
\hline & Patelloida latistrigata & Field expt & Yes & Creese (1982) \\
\hline & Cellana tramoserica & Field expt & Yes & Underwood et al. (1983) \\
\hline
\end{tabular}


selin \& Chia 1995a, but see Mills \& Fish 1980). This has been attributed to a greater surface area to volume ratio (Vermeij 1972), an inferior ability to reduce energy consumption under conditions of stress (Baker \& Mann 1992), and incompletely developed protective adaptations (e.g pigment and calcareous spicules in the ascidian Didemnun molle, OIson 1983). For mobile species, the age dependence of tolerance to physiological stress may depend on the habitats of juveniles and adults. Branch (1975) showed, in the laboratory, that tolerance to desiccation remained fairly constant in non-migratory species of patellid limpets but increased rapidly with size in species which settled low on the shore and migrated upwards as juveniles. Survival of early juvenile invertebrates may also be reduced by stressful physiological conditions which interfere with larval development. Developmental abnormalities associated with extreme physical conditions have been documented (e.g Watts et al. 1983), but their effects on juvenile survival have not yet been investigated.

In the intertidal zone, newly settled invertebrates are highly vulnerable to mortality from desiccation (Table 2) Hatchling whelks (Nucella emarginata) are unable to survive 4 to $6 \mathrm{~h}$ emersion in the field or the laboratory unless they are in a protective microhabitat (Gosselin \& Chi.a 1995a, b). Survival of settlers often decreases with increasing height on the shore. Small barnacles which settle or are transplanted above the limit of the adult distribution generally die (Semibalanus balanoides, Hatton 1938, Foster 1971; Balanus cariosus, Strathmann \& Branscomb 1979; Tetraclitella purpurascens, Denley \& Underwood 1979; Chthamalus anisopoma, Raimondi 1988a, 1991). Hatton (1938) demonstrated that a small amount of dripping water could keep barnacle cyprids alive above the adult zone. Within the vertical range of distribution of adult barnacles, early post-settlement mortality may increase with tidal height $(S$. balanoides, Minchinton \& Scheibling 1991, Bertness et al. 1992; Pollicipes polymerus, Hoffman 1989; C anisopoma, Raimondi 1988 b, 1990) or remain constant (Chthamalus montagui, Kendall. \& Bedford 1987). Early post-settlement mortality also has been shown to increase with tidal height for mussels (Mytilus viridis, Tan 1975) and oysters (Crassostrea virginica, Roegner \& Mann 1995). Lewis \& Bowman (1975) and Bowman \& Lewis (1977) suggested that desiccation was responsible for the restriction of limpet (Patella vulgata) spat on the upper shore to crevices and pits. However, this distribution could also be due to preferential settlement or migration.

Weather and other conditions that influence desiccation rates can account for temporal variability in survival rates of young juveniles. Increased mortality of attached cyprids (Connell 1961) and early post-meta- morphic juveniles (Foster 1971) of the barnacle Semibalanus balanoides has been observed during periods of warm weather and prolonged aerial exposure due to neap tides (Foster 1971) or diminished wave action (Connell 1961). Roegner \& Mann (1995) showed that recently settled oysters (Crassostrea virginica) survived transplantation to $25 \mathrm{~cm}$ above mean low water in September, but not in June or July when aerial temperatures were $>30^{\circ} \mathrm{C}$. Substratum type also can affect the risk of mortality from desiccation. Schubart et al. (1.995) demonstrated that settlement inside empty barnacle tests increased the survival of recently settled barnacles (Balanus glandula) in the high intertidal zone. Minchinton \& Scheibling (1993a) found that early post-settlement mortality of the barmacle $S$. balanoides increased with tidal height in the absence but not in the presence of ephemeral algae. Raimondi (1988b) showed that survival of juvenile barnacles (Chthamalus anisopoma) was reduced at higher tide levels on basaltic rocks compared to granitic rocks, most likely because higher temperatures were attained by basalt. However, rock type did not affect the survival of early juveniles of the barmacle Tesseropora rosea in Australia (Caffey 1982).

Exposure to bright light is a cause of early postsettlement mortality for some species of ascidians (Didemnum candidum, Hurlbut 1993; Didemnum molle, Olson 1983), but not others (Diplosoma listeranium and Diplosoma sp., Hurlbut 1993). Siltation also causes mortality of recently settled ascidians, resulting in greater survival of new settlers on the undersides of panels (Young \& Chia 1984, Hurlbut 1993)

In the laboratory, combinations of extreme temperature and salinity have been shown to cause mortality of recent settlers of several species of invertebrates (Table 2). However, most species tested survived virtually all conditions they are likely to experience in the field (Mills \& Fish 1980, Brown et al. 1992, Chen \& Chen 1993, O'Brien 1994 b). Field estimates of mortality of early juveniles were significantly related to temperature for 1 species of Australian prawn (Penaeus merguiensis, Haywood \& Staples 1993), but not another (Penaeus esculentus, O'Brien 1994a). Laboratory experiments indicated that environmental temperatures were suboptimal for survival. of $P$. merguiensis (Staples \& Heales 1991), but less detrimental to survival of $P$. esculentus (O'Brien 1994b) Also, the field study (O'Brien 1994a) was carried out near the southern limit of the range of $P$. esculentus in Australia, where water temperatures were lower. For estuarine species, periods of anoxia or hypoxia may also be a source of early post-settlement mortality. Baker \& Mann (1992) demonstrated that low levels of oxygen decreased survival of recently settled oysters (Crassostrea virginica) in the laboratory. The absence of 
adult barnacles from tidepools in New England, USA, has been attributed to early post-settlement mortality from decreased dissolved oxygen levels (Singletary \& Shadlou 1983) or accumulation of toxins (e.g. substances secreted by the alga Ulva lactuca, Magre 1974) during tidal isolation. Blooms of toxic dinoflagellates also may result in mortality of early juveniles of benthic invertebrates. Summerson \& Peterson (1990) found that recruitment of the bay scallop Argopecten irradians concentricus was extremely low $(2 \%$ of previous years) during a red tide (Ptychodiscus brevis) outbreak in North Carolina, USA. The increased abundance of empty shells of juvenile scallops after the red tide suggests that the recruitment failure resulted at least partly from elevated early post-settlement mortality.

Despite the vulnerability of recently settled invertebrates to physiological stress, environmental conditions may not commonly cause mortality of early juveniles in the field. Most studies examining survivorship under conditions of physiological stress have transplanted settlers or modified the conditions to which they were exposed. Many individuals may avoid these sources of mortality by settling in (Connell 1961, Denley \& Underwood 1979, Olson 1983, Young \& Chia 1984. Hurlbut 1993. Schubart et al. 1995) or migrating to (Gosselin \& Chia 1995b) locations where environmental conditions are not lethal.

\section{Predation}

\section{Mobile epifauna}

Predation on early juveniles has been documented most often for mobile epifaunal species (Table 3). Fish and crabs are the most commonly reported predators of early juveniles of many species, including lobsters, crabs, shrimp, queen conch, scallops, and sea urchins (Table 3). These were the only types of predators, out of the 45 species of intertidal invertebrates tested in the laboratory by Gosselin \& Chia (1995a), that preyed on recently hatched intertidal whelks (Nucella emarginata). Other predators of early juveniles include shrimp (preying on blue crabs), sea stars (on scallops and urchins), whelks (on scallops), octopus (on spiny lobster), lobster (on urchins), and urchins (on sea cucumbers) (Table 3). Some species of recently settled echinoderms are preyed upon primarily by small predators. In the laboratory, small individuals $(<1.5 \mathrm{~mm})$ of the sand dollar Dendraster excentricus were heavily preyed upon by tanaid crustaceans but not eaten by gammarid amphipods or holothurians (Highsmith 1982). Survival of 1 mo old sea stars (Acanthaster planci and Nardoa novaecaladoniae) in rubble on the Great Barrier Reef, Australia, was decreased by epifauna consisting primarily of polychaetes, amphipods and gastropods (Keesing \& Halford 1992, Keesing et al. 1996), but predators had little effect on survival of another species of Nardoa on the Okinawan Reef, Japan (Keesing et al. 1996). Rumrill (1989) was unable to find any significant predators of juveniles of Asterina miniata when he exposed them to crabs, other sea stars, and fish in the laboratory. Most of the studies of predation on early juveniles of mobile species have involved individuals several weeks to months after settlement (Table 3 ) and the vulnerability of recently settled individuals to predators may differ from that of slightly older juveniles. However, several studies have found high predation rates on settling or recently settled decapods in the laboratory (Lavalli \& Barshaw 1986, Johns \& Mann 1987, Barshaw \& Lavalli 1988, Olmi \& Lipcius 1991, Dittel et al. 1996) and in the field (Eggleston \& Armstrong 1995).

Tethering is the most common technique used to evaluate predation rates on early juveniles of mobile epifaunal species (Table 3) Recent papers have pointed out potential artifacts of tethering (Barbeau \& Scheibling 1994C, Peterson \& Black 1994, ZimmerFaust et al. 1994, Aronson \& Heck 1995, Micheli 1996). For example, tethering may increase predation rates by limiting the escape response of prey, particularly for highly mobile species (Peterson \& Black 1994, ZimmerFaust et al. 1994, Aronson \& Heck 1995), or by decreasing the ability of prey to burrow in certain substrates (Barshaw \& Able 1990). Also, tethering may differentially affect predation by different predators, potentially complicating comparisons of predation rate among predator species (Barbeau \& Scheibling 1994c) and habitats (if predator species composition or behaviour differs among habitats) (Peterson \& Black 1994, Micheli 1996). Despite these artifacts, tethering with thoughtful controls remains an effective way to assess predation on small, mobile invertebrates.

Predator inclusion or exclusion cages also have been widely used to measure predation rates of juveniles of mobile (and sessile) species (Table 3) There are various artifacts of caging (reviewed by Dayton \& Oliver 1980, Hall et al. 1990) which are particularly relevant to studies of juvenile survival and recruitment. By altering the micro-environment (e.g reducing water flow, shading, creating structure), cages may increase settlement rate and/or early post-settlement survival, which may confound an assessment of predator effects. Also, mesh size will determine the size of predators that are manipulated, including those which may not be part of the original experimental design. Thus, effects of excluding a particular predator may be confounded by other smaller and perhaps unknown predators (including juveniles of species that are being manipulated as adults) which can pass through the 
mesh and may even be attracted to cages. As with tethering, the use of adequate procedural controls to evalLate artifactual effects is crucial to the design of any caging experiment. However, only 2 (Denley \& Underwood 1979, Reise 1979) of the 14 studies we reviewed that employed exclusion cages or fences also used inclusion or partial cages/fences to assess cage artifacts (although in Reise's study treatments were not replicated). Two other studies (Keough 1984, Eggleston \& Armstrong 1995) measured settlement or shortterm recruitment rates in caged and uncaged plots to determine if the presence of a cage altered settlement rates. Studies employing predator inclusion cages were less problematic, as most ( 7 out of 8 ) compared mortality or recruitment rates between cages with and without predators, which would share the same artifacts.

The risk of predation for early juveniles may vary with recruit size. In tethering experiments, the mortality rate of small juvenile lobsters (Panulirus argus, Smith \& Hermkind 1992; Homarus americanus, Wahle \& Steneck 1992) was greater than that of larger individuals, but the effect of body size on predation rate on juvenile blue crabs varied among studies (Wilson et al. 1987, 1990, Pile et al. 1996). The effect of juvenile sea scallop size on predation rate depended on predator type, site, and season (Barbeau \& Scheibling 1994a, Barbeau et al. 1994). For some species, predation risk may be greater for intermediate sized individuals than for early juveniles or adults. Gut contents of mobile benthic predators from the Gulf of Maine examined by Ojeda \& Dearborn (1991) contained mostly juveniles or small species of invertebrates, but most predators did not seem to exploit the smallest size range of prey available. The bimodal size distribution commonly observed in sea urchin populations may be the result of increased predation on intermediate sized urchins in transition between the spatial refuge of the cryptic early juvenile stage and the size refuge of adults (for review see Scheibling 1996). Similarly, Wiedermeyer (1994) found that the importance of predation as a source of mortality for juvenile sea cucumbers (Actinopyga echinites) increased over time, and suggested that this increase in mortality resulted from a decrease in cryptic behaviour.

Predation risk for early juveniles varies among habitats and microhabitats for many invertebrate species including scallops, lobsters, crabs (but see Olmi \& Lipcius 1991), shrimp, urchins, and gastropods (but see Scheibling \& Hatcher 1997) (Table 3). Predation intensity is lower in vegetation and other structurally complex substrata (Table 3). Attachment above the bottom on vegetation (Argopecten irradiens, Pohle et al. 1991, Ambrose \& Irlandi 1992) or occurrence near (Dendraster excentricus, Highsmith 1982) or under
(Strongylocentrotus franciscanus, Tegner \& Dayton 1977) adults can also offer protection from predation. Early juveniles of many species occur primarily in these protective habitats (e.g. Tegner \& Dayton 1977. Highsmith 1982, Breen et al. 1985, Wahle \& Steneck 1991. Garcia-Esquivel \& Bricelj 1993, Gosselin \& Chia 1995b). Older juveniles may outgrow their spatial refuges or shift habitats as their vulnerability to predation decreases (Tegner \& Dayton 1977, Scheibling \& Hamm 1991, Smith \& Herrnkind 1992, Garcia-Esquivel \& Bricelj 1993).

Predation risk for early juveniles also can be influenced by physical factors which affect predator-prey interactions. In laboratory and field experiments with juvenile sea scallops (Placopecten magellanicus), predation rate by crabs and sea stars increased with temperature due to increased predator activity and decreased effectiveness of the scallops' escape response (to sea stars) (Barbeau \& Scheibling 1994b, Barbeau et al. 1994). In a tethering experiment with juvenile blue crabs (Callinectes sapidus), Pile et al. (1996) found that mortality was lower during and immediately after a storm than before the storm. They attributed the reduction in mortality to decreased predator activity resulting from altered physical conditions associated with the storm, such as a drop in water temperature, increased turbidity and turbulent flow, and increased salinity. Similarly, Scheibling \& Hatcher (1997) observed that mortality of juvenile snails (Trochus histrio) tethered outside of a spatial refuge (live branching coral) was lowest during a gale which temporarily reduced the abundance of predatory fish.

\section{Infauna}

Early juveniles of macrofauna in soft-bottom communities are vulnerable to predation by a variety of predators. Jensen \& Jensen (1985) suggested that juvenile crabs (Carcinus maenus) were responsible for the rapid decline in the number of juvenile cockles (Cerastoderma edulej after the settlement peak in the Danish Wadden Sea. In the laboratory, C. maenus can consume large numbers of cockles and selectively preys on small individuals (Jensen \& Jensen 1985, Sanchez-Salazar et al. 1987). Reise (1979) found that densities of early juveniles of $C$. edule in cages in the Wadden Sea were reduced in predator inclusion cages with a nereid polychaete or a nemertine, and increased in predator exclusion cages. However, his failure to replicate treatments may have confounded differences between treatments with differences between locations. In Sweden, Möller (1986) found that exclusion of epibenthic predators using cages also increased densities of spat of several species of bivalve, primarily Mya arenaria and $C$. edule. In Chesa- 
peake Bay, USA, Holland et al. (1987) showed that exclusion of fish and crabs increased the peak abundance of macrofaunal recruits in trays of azoic sediment. Beal (1983) found that 2 species of snapping shrimp (Alpheus heterochaelis and Alpheus normanni) selectively prey on small juveniles of the clam Mercenaria mercenaria in the laboratory, suggesting they may be important predators of juvenile macrofauna. Meiofaunal predators (organisms $<0.5 \mathrm{~mm}$ ) also feed on recently settled macrofauna (Thorson 1966, Bell \& Coull 1980). Watzin (1983, 1986) showed that increased densities of turbellarians reduced the survival of spionid and terebellid polychaetes, oligochaetes, and amphipods.

Deposit feeders, particularly surface-feeding species, ingest early juvenile macrofauna, as well as causing mortality by sediment reworking. Thorson (1966) calculated that deposit feeders could ingest large numbers of macrofaunal settlers, but suggested that some settlers may survive passage through the digestive tract. However, Mileikovsky (1974) reviewed reports of the presence of larvae and small juvenile invertebrates in the digestive tracts of deposit feeders and concluded that passage alive through the digestive system is probably rare and does not play an important role in recruitment. In the laboratory, adult polychaetes and crustaceans decrease the survival of recently settled individuals of several species of bivalves (Gemma gemma, Mulinia lateralis, Macoma balthica) and polychaetes (Abarenicola pacifica, Nerinides spp., Nerinopsis sp., Armandia brevis) (Table 3). Elmgren et al. (1986) tested the mechanism for the increased mortality of settlers of the bivalve $M$. balthica in the presence of adult amphipods (Pontoporeia affinis) and found crushed shells of $M$. balthica only in the aquaria in which $P$. affinis were present. Increased sediment depth, which would decrease the probability of physical contact between amphipods and early juvenile clams, increased the survival of $M$. balthica in the presence but not in the absence of $P$. affinis. Weinberg (1984) showed that the deposit-feeding polychaete Polydora ligni ingested recently settled clams ( $G$. gemma) thereby reducing recruitment in the laboratory, but he did not find these clams in the gut contents of polychaetes collected in the field. However, Qian \& Chia (1994) found that recently settled polychaetes (Capitella sp. I), which were marked with red dye and transplanted to the field, had high mortality in trays containing large numbers of deposit-feeding polychaetes and other predators.

\section{Sessile species}

Exclusion of macrofaunal predators often results in increased recruitment of sessile subtidal invertebrates, which can ultimately affect community structure (Table 3). In California (USA), Keough \& Downes $(1982,1986)$ examined the effects of predators on patterns of recruitment of sessile invertebrates on subtidal rock walls off Santa Catalina Island. Exclusion of predators (fish and urchins) with cages altered the abundance (the bryozoan Tubilopora spp.), spatial distribution (Tubilopora spp., the ascidian Trididemmum opacum), and size distribution (the bryozoan Scrupocellaria bertholetti) of recruits of several species, but had little effect on other species (the bryozoan Celleporaria brunnea, the polychaete Spirorbis eximus). In South Africa, Barkai \& Branch (1988) demonstrated that high densities of rock lobsters prevented recruitment on uncaged plates in the subtidal zone of Malgas Island, while caged plates developed a community of barnacles and mussels. Caging also increased recruitment, although less dramatically, on plates at nearby Marcus Island where rock lobsters were nearly absent and whelks (Burnupena spp.) were the most abundant predators. Caging studies also have shown that predation on recent settlers has a major effect on the structure of fouling communities in New England. The small gastropods Anachis lafresnayi and Mitrella lunata prey on newly settled ascidians, resulting in a shift of community dominance from ascidians to bryozoans (Osman et al. 1992, Osman \& Whitlach 1995a)

Predation by whelks is well known to be an important source of post-recruitment mortality for sessile invertebrates in the intertidal zone (e.g. Connell 1961, 1970, Dayton 1971, Menge 1976). However, studies of the effect of whelks on recently settled invertebrates have yielded conflicting results. Exclusion of the whelk Morula marginalba had no effect on survival of the barnacle Tesseropora rosea in the first few months after settlement in Australia (Denley \& Underwood 1979). In contrast, Menge (1991) found that recruitment of the barnacle Balanus inexpectatus in Panama was lower in the presence of predatory gastropods (including whelks), and that recruitment of the bivalves Chama echinata and Ostrea palmula was lower in the presence of various predators (gastropods, crabs, fish). However, gastropod removal treatments and controls were pseudoreplicated in his study, confounding differences between locations with differences between treatments. Carroll (1996) found that exclusion of whelks and sea stars increased recruitment of barnacles (Semibalanus balanoides, $S$. cariosus, $B$. glandula) in Alaska, USA, in a year with low settler densities, but had no effect in 2 years with higher settlement. In Maine, USA, the whelk Nucella lapillus had little (Petraitis 1991) or no (Petraitis 1990) effect on recruitment of the mussel Mytilus edulis. In southern Chile, Moreno (1995) found that recently settled mussels (Choromytilus chorus) only survived on 


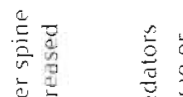

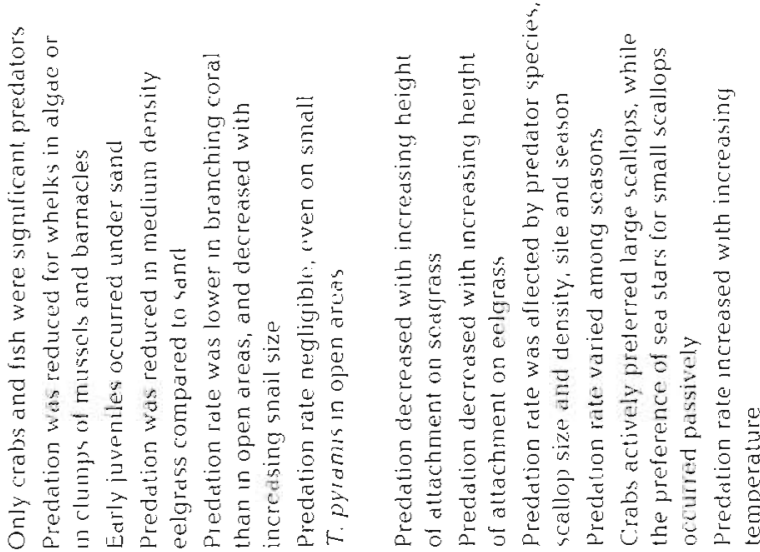

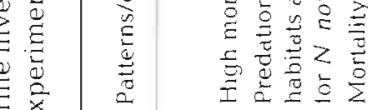

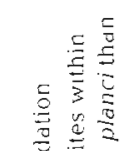

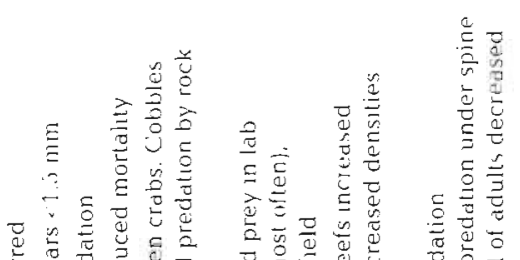

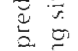

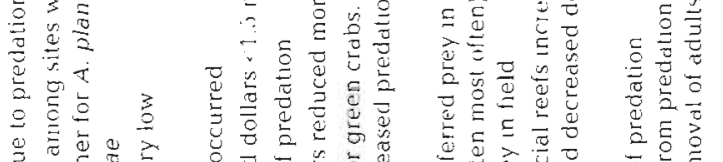

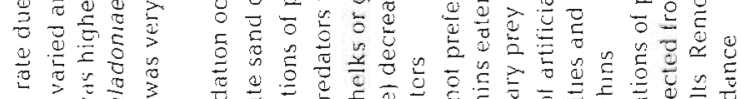

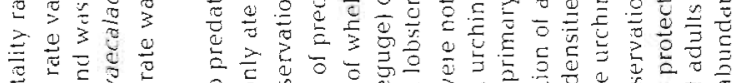

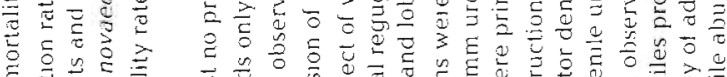

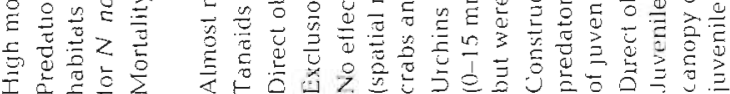

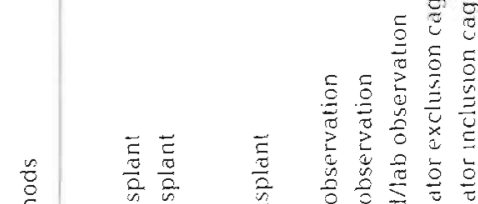<smiles>C1CCC23CC(CC2C1)C3</smiles><smiles>C[C@H]1C[C@@H](C)C1</smiles>

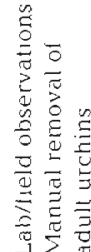<smiles>C[C@@H]1C[C@@H]2C[C@H]1C[C@H]2C</smiles>

\section{昰}

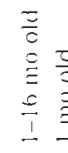

$\frac{5}{c}$
$\frac{5}{5}$
$i n$

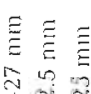

0

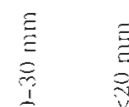

豆章

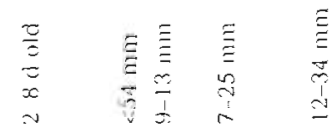
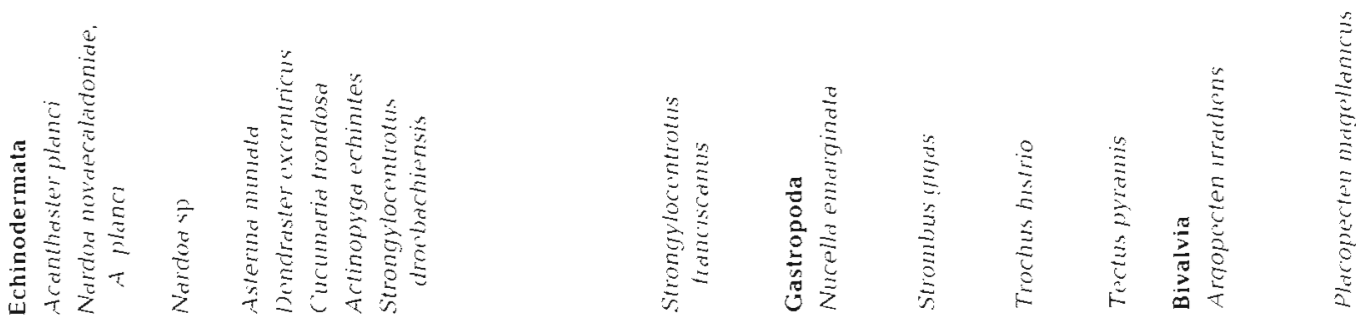


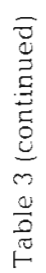

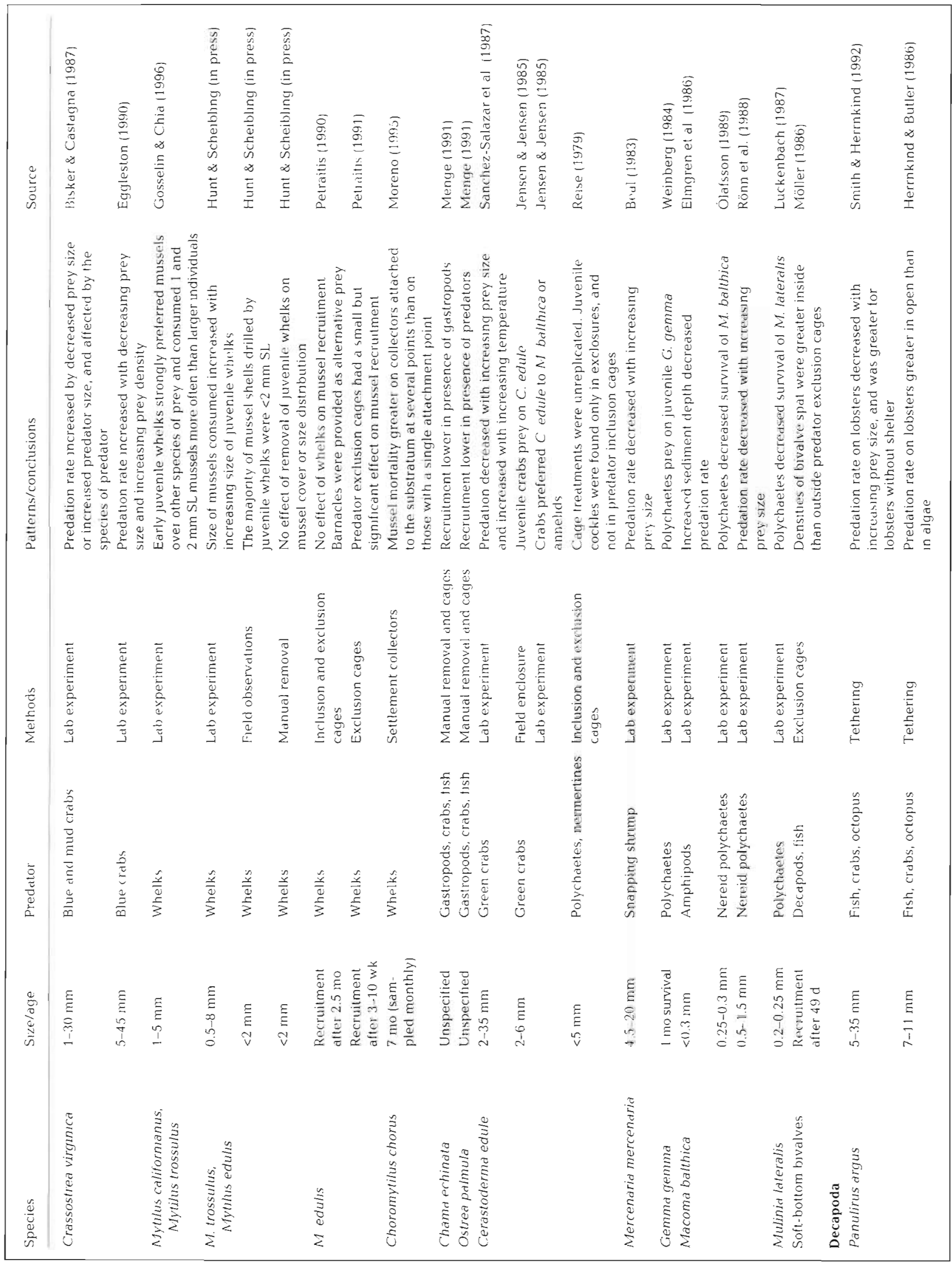




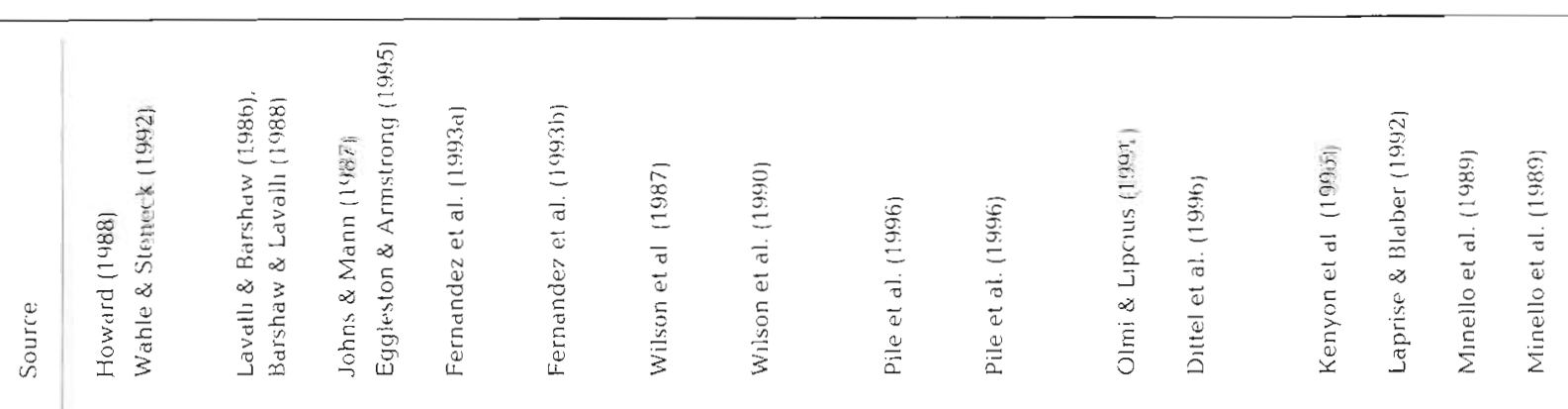

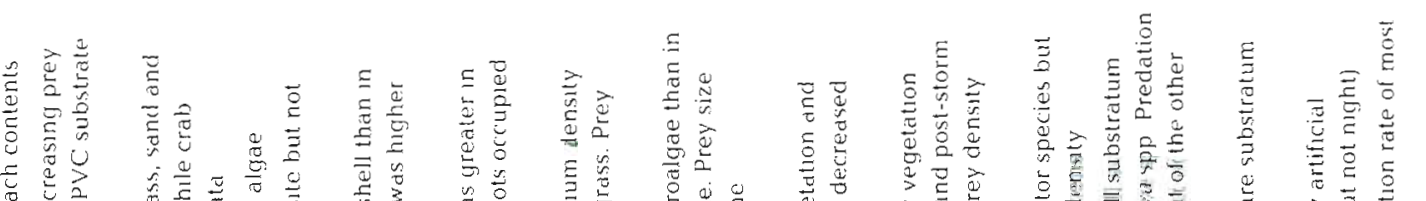

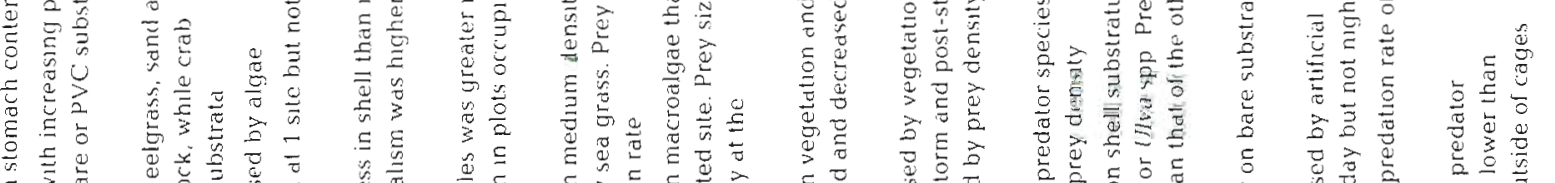

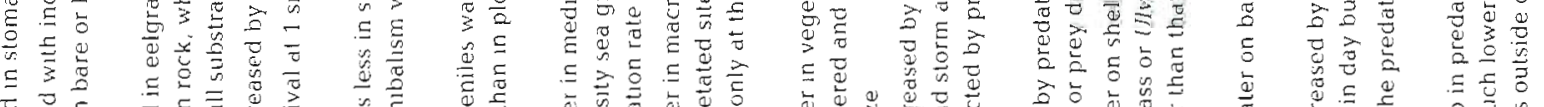

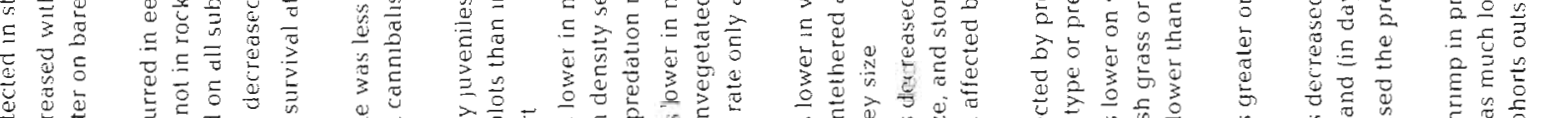

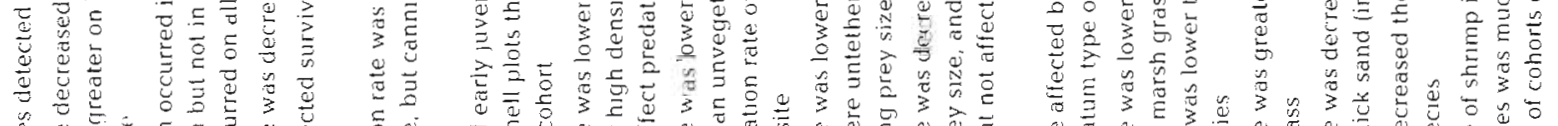

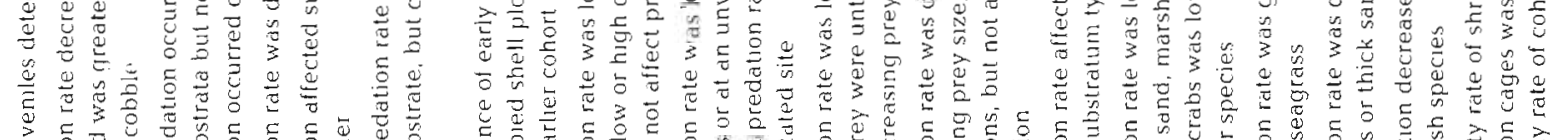

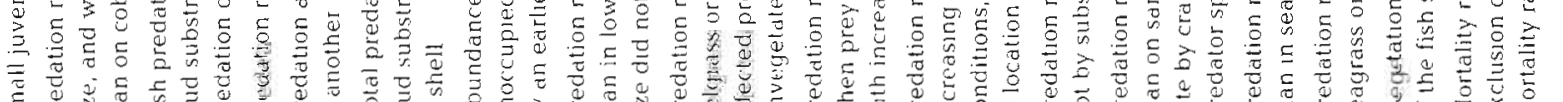

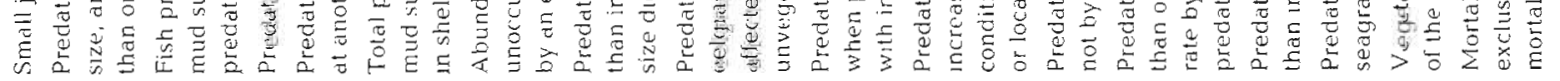<smiles>C[C@H]1C[C@@H](C)[C@@H]1C</smiles><smiles>CC1C[C@@H](C)[C@H](C)C1</smiles>

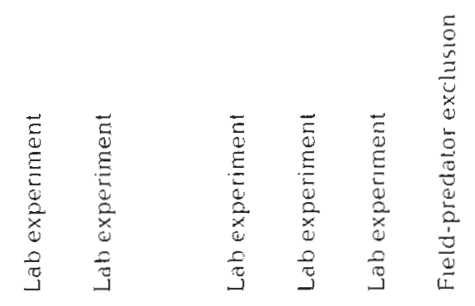

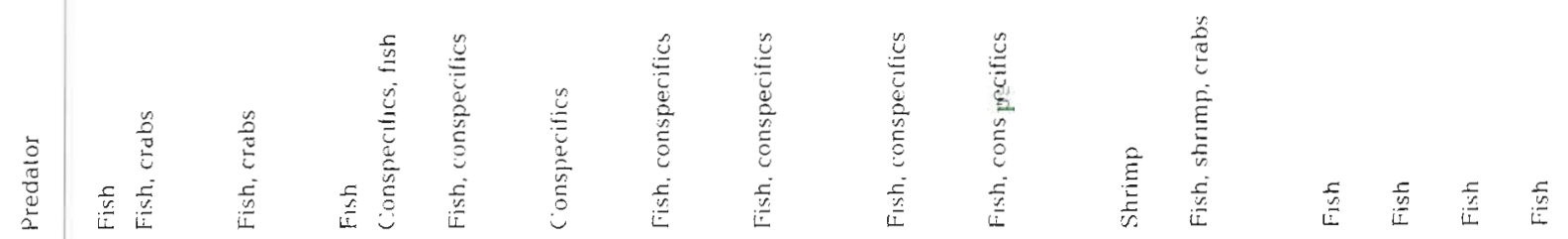

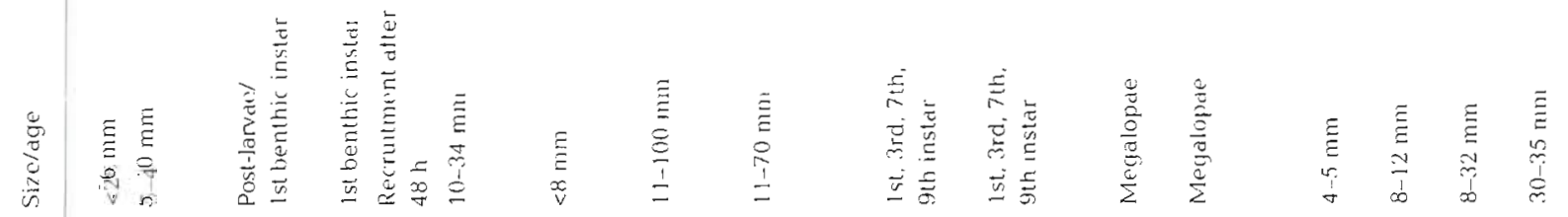
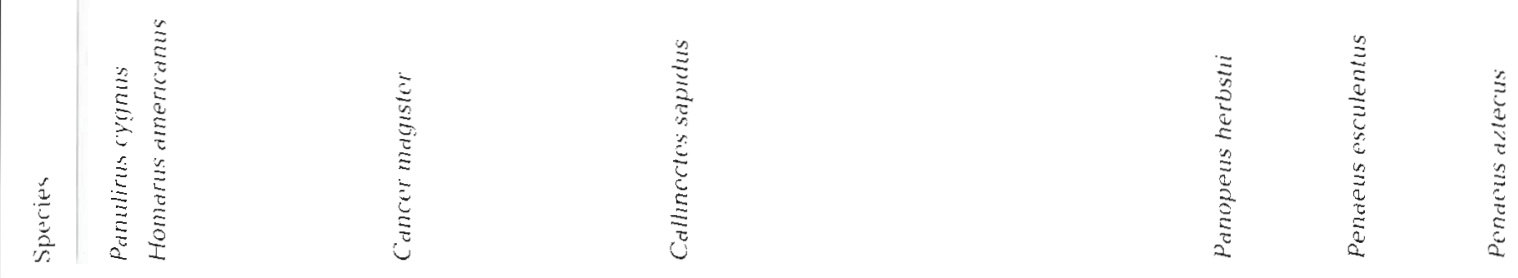


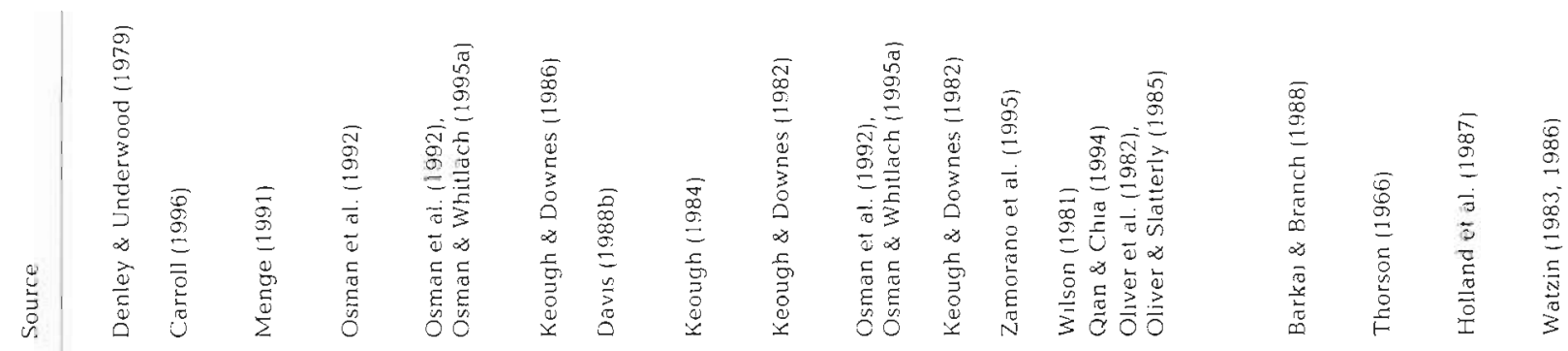
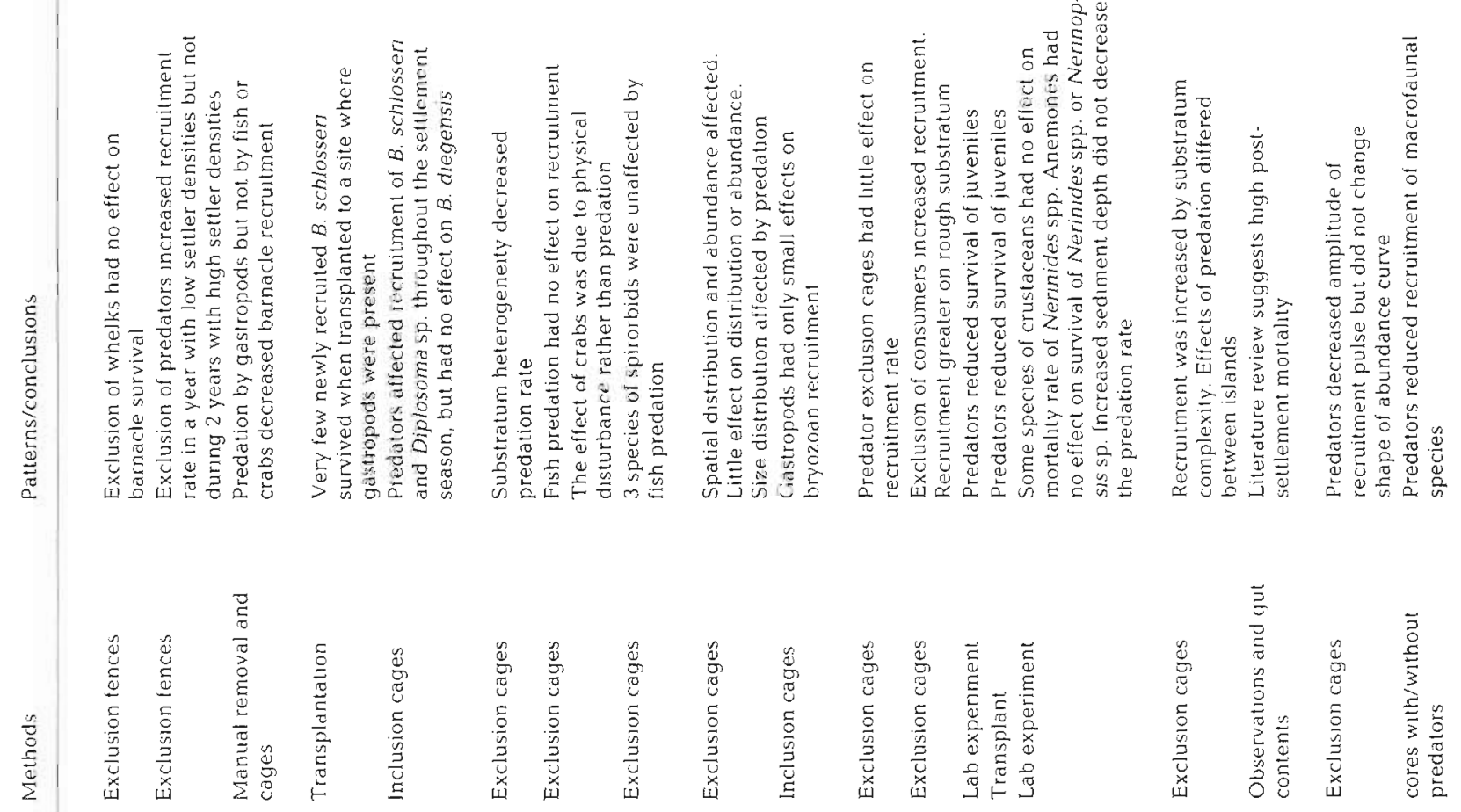

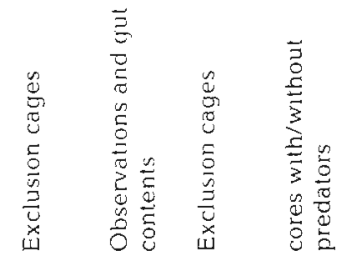

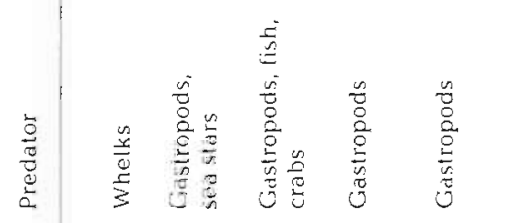

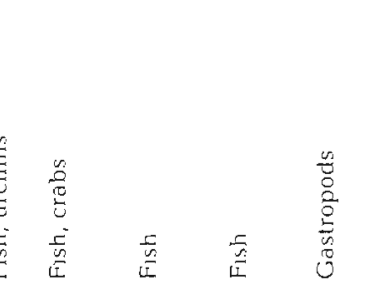

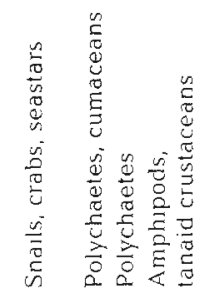

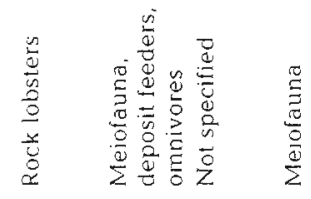

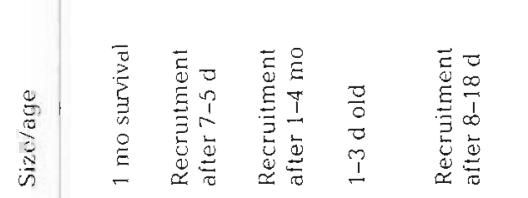

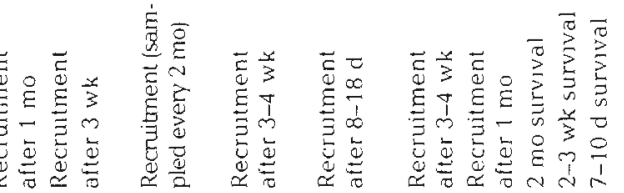

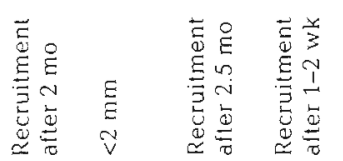
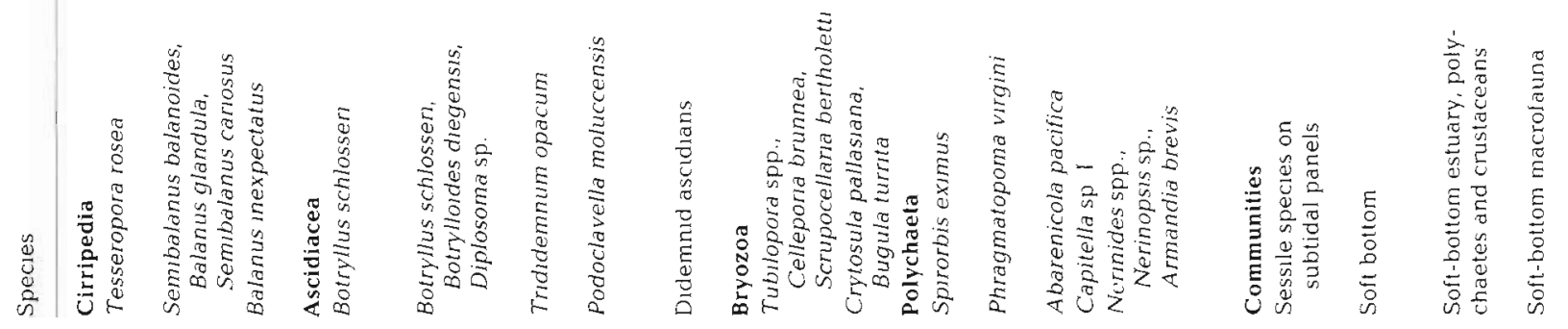
filamentous algae or artificial collectors which were inaccessible to the whelk Nucella crassilabrum. How ever, much of the whelk predation probably occurred several weeks to months after the mussels settled. Also in southen Chile, exclusion of all consumers (whelks and other carnivorous gastropods, crabs, and sea stars) increased recruitment of the reef-building polychaete Phragmatopoma virgini (Zamorano et al. 1995)

Researchers investigating predation on older individuals have commented that adult whelks were not observed feeding on newly settled barnacles (Semibalanus balanoides, Connell 1961; Tesseropora rosea, Fairweather 1988), although Connell (1970) noted that Balanus glandula was attacked by predators (primarily 3 species of Nucella) soon after settlement. Whelk recruits are probably more important predators of recently settled barnacles and mussels than adult whelks. In the laboratory, Gosselin \& Chia (1996) found that 15 to $18 \mathrm{~d}$ old Nucella emarginata strongly preferred Mytilus californianus and Mytilus trossulus over 4 other species presented (the barnacles B. glandula, Chthamalus dalli and Pollicipes polymerus and the bivalve Lasaea sp.). The whelks preferentially consumed the smallest ( 1 and $2 \mathrm{~mm}$ shell length) size classes of mussels offered. Hunt \& Scheibling (in press) found that recruits $(<5 \mathrm{~mm} \mathrm{SL}$ ) of Nucella lapillus prey on a range of sizes of mussels ( $M$. trossulus and Mytilus edulis) in the field and the laboratory, including individuals $<1 \mathrm{~mm}$ shell length. Reduction of the density of recently recruited whelks had no effect on either cover or size distribution of Mytilus spp. However, manual removal of whelk recruits was not very effective because the high densities of recruits necessitated a small spatial scale of manipulation that was difficult to maintain

A number of factors can modify the intensity of predation on recent settlers of sessile species. In the laboratory, predation on juvenile oysters (Crassostrea virginica) by blue crabs (Callinectes sapidus) decreases with increasing oyster size (Bisker \& Castagna 1987. Eggleston 19901. For colonial species, the consequences of predation may also be greater for early juveniles than for adults. Davis (1988b) demonstrated that removal of all zooids (to simulate predation) of the ascidian Podoclavella moluccensis killed all juvenile $(2$ to 3 mo old) colonies in $<24$ d but did not cause mortality of adults which quickly regenerated. Certain substrata can offer protection from predation, as described above for mussels (Moreno 1995) Settlement beside adults decreased mortality of recently settled octocorals (Alcyonium siderium), most likely because adults prevented urchin grazing (Sebens 1983). Protection from predation is probably also the reason for the increased survival of early juvenile vermetid gastropods which settle on bryozoans (Osman 1987).

\section{Competition for space and food}

For recently settled invertebrates, particularly sessile ones, overgrowth is an important cause of mortality. Overgrowth by algae is associated with decreased survival of recently settled corals (Pocillopora damicornis, Harriott 1983), ascidians (Young \& Chia 1984), barnacles (Tetraclitella purpurascens, Tesseropora rosea, Denley \& Underwood 1979), and limpets (Patelloida latistrigata, Creese 1982). Survival of early juveniles is increased by inctors which decrease algal abundance, such as shade for ascidians (Young \& Chia 1984) and the presence of adult limpets for the limpet $P$. latistrigata (Creese 1982).

Overgrowth by other invertebrates is a common cause of mortality for encrusting species (e.g. Buss 1979, 1981, Grosberg 1981), and new settlers may be particularly vulnerable. Overgrowth by ascidians has been suggested as a cause of mortality for early juveniles of the octocoral Alcyonium siderium (Sebens 1983) and the bryozoan Bugula pacifica (Young \& Chia 1981), and for several members of the fouling community in Long Island Sound, USA (Osman \& Whitlach $1995 b)$ Overgrowth also was the likely cause of decreased survival of settlers of the coral Capnella gaboensis on biofilmed substrata compared to bare substrata in the laboratory (Farrant 1987). In New South Wales, Australia, Denley \& Underwood (1979) showed that survival of newly settled barnacles (Tetraclitella purpurascens) in the low intertidal zone was increased by removal of settling polychaetes (Galeolaria caespitosa). Also in Australia, mortality of the subtidal colonial ascidian Podoclavella moluccensis in the first month after settlement varied among sponge and bare wood substrata due to differences in the risks of overgrowth and dislodgment of substrata: ascidians preferentially settled on substrata on which their survival was increased (Davis 1987). Crowding and overgrowth in dense aggregations of settlers can result in density-dependent early post-settlement mortality (Weiss 1948), although crowding is more likely to cause post-recruitment mortality as the recruits grow and begin to contact one another Flexibility of hody form can lessen the effects of crowding Young \& Braithwaite (1980) reported that gregarious settlers of the ascidian Chelyosoma productum produce an epidermal ampulla to access the overlying water column for space to grow.

Limitation of food intake also can cause early postsettlement mortality. In laboratory and field experiments, mortality of newly settled oysters (Crassostrea virginicd increased with the density of fouling species possibly due to food depletion (Osman et al. 1989 Zajac et a.l. 1989), although some overyrowth occurred (Osman et al. 1989). Increased food supply in the labo- 
ratory experiments had mixed effects on oyster spat survival, initially ameliorating density effects and later exacerbating them (Zajac et al. 1989). Underwood et al. (1983) showed that barnacles reduced survivorship of recruits of the limpet Cellana tramoserica, probably by decreasing the space available for grazing. In sedimentary habitats, competition for food may be less important as a source of early post-settlement mortality. Although recruitment rates of several species of bivalves in soft-bottom habitats are inversely related to the density of adult conspecifics (e.g. Peterson 1979. Möller 1986, Thrush et al. 1996), this is attributed primarily to a reduction in settling larvae by filter feeding adults rather than early juvenile mortality (Ólafsson et al. 1994). For example, Williams (1980b) found that settlement of clams (Tapes japonica) on a beach in Washington was greater in areas with low or moderate densities of adult clams, but adult density had no effect on survival of early juvenile clams (Williams 1980a).

\section{RECRUIT-SETTLER RELATIONSHIP}

\section{Relationship between recruit and settler density}

A positive relationship between the abundances of recruits and settlers (measured at 1 to $4 \mathrm{~d}$ intervals) has been found in most studies of sessile species (mainly barnacles). Recruitment of the barnacle Chthamalus fissus in Costa Rica reflected settlement for the first 120 d (Sutherland 1990). Similarly, settlement explained $>70 \%$ of the variance in the number of Chthanalus anisopoma reaching maturity $16 \mathrm{wk}$ of age) in the Gulf of California, Mexico (Raimondi 1990), and in the abundance of Semibalanus balanoides recruits at the end of the main settlement season in Nova Scotia, Canada (Minchinton \& Scheibling 1991). Connell's (1985) analysis of unpublished data from several studies of barnacles revealed a positive relationship between recruit and settler density for Tesseropora rosea at 2 of 3 shore levels in Australia, and for $S$ balanoides in England but not in Scotland or in Massachusetts, USA. In Rhode Island, USA, Bertness et al. (1996) found that interannual differences in abundance and distribution of recruits of $S$. balanoides reflected settlement patterns associated with windinduced changes in larval concentrations. Davis (1988a) monitored settlement of the colonial ascidian Podoclavella moluccensis on wooden pilings in South Australia and found that settlement explained $86 \%$ of the variation in recruitment 1 mo later. In California, zooid density of 2 to $4 \mathrm{wk}$ old bryozoans (Membranipora membranacea) was prinarily related $(68 \%$ of variance) to recruitment, which was monitored biweekly (Yoshioka 1986).
Studies of the relationship between recruit and settler abundance for mobile species have produced variable results. In North Carolina, density of settlers of the bay scallop Argopecten irradians concentricus on spat collectors explained $71 \%$ of the variance in the number of recruits 2 mo later in 1988, but only $4 \%$ in 1989 when settlement was very high at 2 sites (Peterson \& Summerson 1992). Herrnkind \& Butler (1994) were unable to make consistent, accurate predictions of recruitment of the spiny lobster (Panulirus argus) over 3 yr in Florida Bay, USA, based on samples of lobster larvae in the plankton, settlers on floating and benthic collectors, and information on geography and substratum type. More accurate models were generated based on data from a single year, but the most influential variables varied from year to year Butler \& Herrnkind (1997) experimentally tested the importance of settler abundance and availability of shelters for recruitment of $P$. argus. They found that the number of small juvenile lobsters increased at sites where artificial shelters were added, apparently as a result of reduced predation on small juveniles, but did not measurably increase from the addition of new settlers. In New Zealand, Morgan et al. (1982) found no clear relationship between density of juveniles of the rock lobster Panulirus cygnus and density of settlers on collectors 1 to 1.3 yr earlier, although Chittleborough \& Phillips (1975) had reported a significant relationship based on a smaller portion of the same data set. However, Phillips (1990) suggested that the estimates of densities of juvenile rock lobsters, based on mark-recapture methods, are inaccurate due to migration of lobsters among reefs. There appears to be a stronger relationship between abundances of the early life history stages of the American lobster Homarus americanus in the Gulf of Maine, USA. Incze \& Wahle (1991) found that the number of 1 yr old lobsters (10 to $16 \mathrm{~mm}$ ) was significantly correlated with the density of recent benthic recruits ( 7 to $8 \mathrm{~mm}$ carapace length) sampled the previous year. In Australia, the density of juvenile ( $>3$ mm carapace length) tiger prawns (Penaeus semisulcatus) was related to the density of recently settled benthic postlarvae $(<3 \mathrm{~mm}) 2$ wk earlier (Vance et al. 1996)

For soft-bottom communities, studies examining temporal variability in early juvenile densities provide some information about the recruit-settler relationship. Muus (1973) monitored densities of 11 species of infaunal bivalves ( $<2 \mathrm{~mm}$ shell length) in Denmark. Abundances of most species decreased rapidly after settlement peaked and leveled off at a density unrelated to the peak settler abundance. In South Carolina, USA, Feller et al. (1992) examined the correspondence between peaks of abundance of meiofaunal $(<0.5 \mathrm{~mm})$ and macrofaunal-sized $(>0.5 \mathrm{~mm})$ polychaetes and 
bivalves in sediment samples and larvae in plankton tows. There was better correspondence between peaks of abundance of meiofaunal-sized individuals and planktonic larvae than between macrofauna and larvae, or between macrofauna and meiofauna, suggesting that mortality of new settlers was variable

McGuinness \& Davis (1989) have suggested that using correlation or regression to analyze the relationship between recruit and settler abundance (as was done in most studies described above) is not appropriate because recruit density is constrained to be equal to or less than settler density. However, the relationship between recruitment and settlement in these studies is generally clear even without the use of statistics. McGuinness \& Davis (1989) suggested that statistical analyses should be confined to the relationship between mortality and initial settler density. Analysis of the relationship between mortality and settler density is useful, but may not reveal whether spatial or temporal patterns of recruitment reflect differences in settlement (see next section)

\section{Under what conditions are recruit and settler densities positively related?}

Connell (1985) suggested that recruitment will reflect settlement only when early post-settlement mortality is density independent. However, Holm (1990) pointed out that settlement and recruitment may still be positively related when mortality is weakly density dependent. When mortality is positively density dependent, predictions of recruitment will be most accurate when settler densities are low, whereas when mortality is inversely density dependent, predictions will be most accurate at high settler densities (Holm 1990).

Positive density dependence of early post-settlement mortality may result from density-dependent predation (Gaines \& Roughgarden 1985, Hurlbut 1991a, c), lack of suitable settlement sites (McShane 1991) or crowding (Weiss 1948). Crowding may be a less important cause of density-dependent mortality for recent settlers than it is for recruits which have grown large enough to contact one another (e.g. barnacles, Grant 1977. Denley \& Underwood 1979, Bertness 1989, Stephens \& Bertness 1991). Inversely density-dependent mortality of recent settlers may arise when conspecific settlers provide protection to one another from harsh physical conditions, as is the case for postrecruitment mortality of the barnacle Semibalanus balanoides in the high intertidal zone (Bertness 1989 , Stephens \& Bertness 1991).

Studies have reported a positive relationship between recruitment and settlement when mortality was density independent (most studies analyzed by Connell 1985, Davis 1988a, Raimondi 1990, Minchinton \& Scheibling 1991) or inversely density dependent (Minchinton \& Scheibling 1991). Mcciuinness \& Davis (1989) reanalyzed the data of Davis (1988a) by weighted least-squares regression (to meet the assumption of homogeneity of variances), and those of Caffey (from Connell 1985) by pooling observations, and found significant inversely density-dependent mortality. These studies, all but 1 of which involved barnacles, are the only ones to have simultaneously examined the relationship between recruit and settler abundance and the density dependence of early postsettlement mortality. No consistent trend in the density dependence of early mortality has emerged from other studies of sessile invertebrates. Early post-settlement mortality was positively density dependent for the ascidian Didemnum candidum on floating docks (Hurlbut 1991c) and for barnacles (predominantly Balanus improvisus) on settlement panels (Weiss 1948). Hurlbut (1991a) found that mortality of $1 \mathrm{~d}$ old juveniles was density dependent for the 3 most abundant settlers on subtidal plates (the serpulid polychaete Hydroides elegans, the bivalve Anomia nobilis, and the bryozoan Schizoporella unicornis) but not for the less abundant ascidians (Phallusia nigra, D. candidum, Diplosoma listeranium, and Diplosoma sp.). In laboratory studies, survivors of the coral Porities porities were clumped (Goreau et al. 1981), suggesting inversely densitydependent mortality, while early post-settlement mortality of the oyster Crassostrea virginica was density independent (Roegner 1991). Mortality of bryozoans (Bugula neritina) transplanted to the field on artificial seagrass blades was either inversely density dependent or had no trend with density (Keough 1986 , Keough \& Chernoff 1987).

The density dependence of early post-settlement mortality of mobile species has been examined in fewer studies. McShane (1991) found that the decrease in recruit density (after $5 \mathrm{mo}$ ) of the abalone Haliotis rubra in southeastern Australia depended on initial recruit density. In contrast, Haywood \& Staples (1993) reported that mortality rate of cohorts of the prawn Penaeus merguiensis was not significantly related to prawn density, although densities decreased dramatically within 2 wk of settlement regardless of initial density. Guillou \& Tartu (1994) found that the decline in density of the bivalve Cerastoderma edule during the early post-settlement period was not clearly related to initial recruit density. Early post-settlement mortality of sea stars (Acanthaster planci) transplanted to the field was density independent (Keesing et al. 1996). Pile et al. (1996) found a hyperbolic relationship between densities of small instars of the blue crab Callinectes sapidus, indicating density-dependent proc- 
esses. They suggested that this relationship was more likely due to emigration from the nursery habitat than to mortality.

Temporal or spatial variability in mortality may obscure any relationship between recruitment and settlement, even if early post-settlement mortality is density independent (Holm 1990). In the laboratory, Roegner (1991) found that temporal variability of mortality of the oyster Crassosstrea virginica precluded estimation of recruit density from settler density, despite density-independent mortality.

\section{EFFECTS OF SETTLEMENT AND EARLY POST-SETTLEMENT MORTALITY ON RECRUIT DISTRIBUTION}

\section{Sessile species}

\section{Association with substrata}

Both selective settlement and early post-settlement mortality determine the distribution of recruits at small spatial scales, such as among microhabitats on the substratum. In California, USA, recruits of the ascidian Trididemnum opacum occurred primarily in pits and crevices because of both selective settlement and predation of more exposed settlers by fish and urchins (Keough \& Downes 1986). Fish predation also determined the spatial distribution of recruits of the bryozoan Tubulipora spp., such that recruit abundance was related to the proportional surface area of microhabitat refuges, but it did not affect the distributions of 2 other bryozoans (Scrupocellaria bertholetti and Celleporaria brunnea) or a polychaete (Spirorbis eximus) (Keough \& Downes 1982). In North Carolina, early post-settlement mortality did not modify the distribution of recently settled barnacles (Balanus amphitrite) and bryozoans (Bugula neritina) on an artificial substrata (Lego) with uniformly spaced roughness elements (Walters 1992). Walters \& Wethey (1996) found that both species selectively settled between the 'bumps', which acted as refuges from predation during the first week after settlement. Larvae of 2 species (the bryozoan Schizoporella errata and the hydrozoan Tubularia crocea) with unlimited growth along the substrata (clonal encrusting and stolon-mat forms respectively) were less specific in their settlement locations and grew out of refuge locations within days (Walters \& Wethey 1996).

Recruits of sessile species are also non-randomly distributed at small spatial scales on biotic substrata. In South Carolina, Young (1991) found that preferential settlement resulted in greater recruitment of the bar. nacle Chthamalus fragilis in the axils of cordgrass
(Spartina alterniflora), despite higher early post-settlement mortality in this location. In contrast, the distribution of the bryozoan Bugula neritina on seagrass (Thalassia testudium) blades in Florida (USA) resulted more from early mortality than from differential settlement (Keough 1986). Mortality of newly settled bryozoans on artificial seagrass blades transplanted to the field was lowest on the distal (oldest) parts of the blades where most adult colonies occurred; settlement accounted for $<20 \%$ of the deviation from a uniform distribution (Keough 1986). Early post-settlement mortality also appeared to be important in determining the distribution of the colonial hydroid Hydractinia echinata on hermit crab shells (Yund et al. 1987). The entire surface of the shells was covered by settlementinducing bacteria, but extensive differential mortality of juveniles resulted in the concentration of recruits on the undersurface of the shell, particularly at the aperture and siphon where polyps were bathed in the crab's feeding currents (Yund et al. 1987).

Early post-settlement mortality can also alter the association of settlers with particular substrata. Gotelli (1987) found that the association of the compound ascidian Aplidium stellatum with vertical surfaces in the field was stronger than the preference of larvae for vertical substrata in the laboratory, suggesting that juvenile mortality also contributed to the distributional pattern. Hurlbut (1991b) compared the distribution of settlers, juveniles, and adults of 2 species of bryozoans (Flustrellidra hispida and Alcyonidium polyoum) on various substrata in the rocky intertidal zone in New Hampshire, USA. For both species, survival of new settlers appeared to differ among substrata. The distribution of F. hispida seemed to result mainly from selective settlement on the most abundant alga, Ascophylum nodosum. However, A. polyoum occurred mainly on rock, although it selectively settled on the relatively rare algae Fucus distichus and Chondrus crispus. Osman (1987) found that the vermetid gastropod Serpulorbis squamigerus recruited primarily on encrusting bryozoans. Based on observations of newly settled individuals and measures of post-recruitment mortality, he suggested that although the general association of Serpulorbis with bryozoans resulted from both settlement and early post-settlement mortality, differences in recruitment among different bryozoan substrata were caused primarily by mortality.

\section{Vertical distribution}

The relative importance of settlement and early postsettlement mortality in determining the vertical distribution of barnacles differs among species. Numerous studies have noted that barnacles settle above the dis- 
tributional limit of adults, usually in very small numbers, and that many of these settlers die shortly after settlement (for review see Connell 1985). The vertical distributions of some species of barnacles (Tesseropora rosea and Tetraclitella purpurascens, Denley \& Underwood 1979; Chthamalus anisopoma, Raimondi 1988a, 1991) have been attributed to settlement patterns. The vertical range of settlement can be limited by the vertical distribution of larvae in the water column ( $B a l-$ anus crenatus and Balanus glandula, Grosberg 1982), induction of settlement by conspecifics $(C$. anisopoma Raimondi 1988a, 1991), or larval avoidance of cues present on the upper shore (Balanus cariosus, Strathmann \& Branscomb 1979). The frequency of settlement above the upper limit of adults can vary among geographic locations (Wethey 1984).

The abundance of recruits of subtidal sessile species often varies with depth. On floating docks in Hawaii, USA, non-random settlement resulted in greater abundance of the colonial ascidian Didemnum candidum at $0.25 \mathrm{~m}$ than $6 \mathrm{~m}$ depth, despite high densitydependent mortality of settlers (Hurlbut 1991c). Stoner $(1990,1992)$ demonstrated that vertical zonation of recruits of the ascidian Diplosoma similis in Hawaii was determined by directional larval swimming and active site selection. In contrast, post-settlement mortality appeared to determine the upper depth limit of subtidal ascidians in Florida (Dalby \& Young 1992). The lack of recruits in the intertidal oyster zone did not result from larval zonation, as ascidians recruited to floating plates in this zone. Adults transplanted to the oyster zone died, primarily from physiological stress during emersion (e.g. desiccation, insolation, osmotic shock, or freezing), suggesting that new settlers, which are likely more vulnerable to these stresses, experience high mortality in this zone (Dalby \& Young 1992).

\section{Horizontal distribution}

At horizontal scales of hundreds of metres to kilometres, early post-settlement mortality appears to be less important than settlement in determining the distribution of recruits of sessile species. Gaines \& Roughgarden (1985) attributed differences in the abundance of the barnacle Balanus glandula between 2 sites on a rocky shore in California to settlement rate since survivorship was similar or greater at the site with lower barnacle abundance. In the San Juan Archipelago, USA, Shanks \& Wright (1987) found that barnacle cyprids were abundant in the convergence zone of internal waves, suggesting that cyprids (and other larvae) can be transported shoreward by these waves. Recruitment of barnacles (B. glandula, Semi- balanus cariosus) was greater in areas of a bay where surface drifters were frequently transported by internal waves than in areas where drifters were seldom transported. In the intertidal zone of Galveston Bay, Texas, USA, differential settlement results in domination by oysters (Crassostrea virginica) within $10 \mathrm{~m}$ of shore and by barnacles (Balanus eburneus) further from shore (Bushek 1988). Greater settlement of barnacles on the farther pilings was attributed to both preferential settlement and a higher rate of larval supply due to greater water motion (Bushek 1988). Hunt \& Scheibling (1996) found that the pattern of distribution of mussel (Mytilus trossulus, $M$. edulis) recruits among intertidal habitats (ice-scoured and non-scoured tidepools and emergent rock) corresponded to the pattern of settlement. Bingham (1992) showed that the distribution of epifaunal species among channels in a mangrove island in Florida was best explained by larval supply; early post-settlement mortality of settlers transplanted on panels was low. and varied among channels for only 1 of 5 species tested. A short larval. lifespan appeared to explain the absence of the bryozoan Bugula neritina from some suitable sites in seagrass beds in Florida. Keough \& Chernoff (1987) found that early post-settlement mortality of transplanted bryozoans was lower at sites where adults were absent, suggesting that the patchy adult distribution results from limited dispersal of the short-lived larvae rather than from post-settlement mortality. In a lagoon in the Great Barrier Reef, Olson (1985) showed that the distribution of recruits and adults of the colonial ascidian Didemnum molle matched the dispersal pattern of the short-lived larval stage, indicating that early post-settlement mortality (which was not measured) did not modify the distribution of settlers. Also on the Great Barrier Reef, Sammarco \& Andrews (1989) found that coral recruitment on plates decreased with distance from the reef, even though early post-settlement mortality due to overgrowth was higher on and directly adjacent to the reef. Coral spat were concentrated at stations with high water residence times.

Early post-settlement mortality appears to be responsible for the dominance of bryozoans in some New England fouling communities, although the contributions of larval supply and settlement to this pattern have not been examined. Osman et al. (1992) and Osman \& Whitlach (1995a) found that micropredators (the gastropods Anachis lafresnayi and Mitrella lunata) dramatically reduced the recruitment of ascidians, resulting in dominance by bryozoans. The gastropods were fairly specific in their prey preference and were capable of affecting the recruitment of ascidians throughout the settlement season (Osman \& W'hitlach 1995a). 


\section{Mobile species}

The distributional pattern of settlers of mobile species can be modified by migration (e.g. the sea cucumber Psolus chitonoides, Young \& Chia 1982; the gastropod Lacuna vincta, Martel \& Chia 1991) as well as early post-settlement mortality. Movement frequency of early juveniles of some species can be high. For example, Armonies (1994) estimated that juvenile bivalves (Macoma balthica and Cerastoderma edule) in a soft-bottom community in the German Wadden Sea moved at least once a week during summer For species with high rates of movement, patterns of settlement and early post-settlement mortality are likely to influence the distribution of recruits only at scales larger than that of the movement of early juveniles.

Several studies have found evidence that early postsettlement mortality influences the distribution of recruits of mobile epifaund. Eggleston \& Armstrong (1995) found that differences between sites in settlement rate of Dungeness crab (Cancer magister) attributed to postlarval supply disappeared in less than $48 \mathrm{~h}$ outside predator exclusion cages. The high densities of juveniles of the red and purple sea urchins Strongylocentrotus franciscanus and Strongylocentrotus purpuratus beneath or near adults also have been attributed to early post-settlement mortality rather than preferential settlement or migration (Cameron \& Schroeter 1980). However, Breen et al. (1985) found that juveniles of $S$. franciscanus in laboratory experiments actively associated with adults, particularly in the presence of predators, and suggested that the association in nature was due to migration rather than mortality. Early post-settlement mortality also has been implicated as a cause of between-habitat differences in the distributions of $S$. franciscanus and $S$. purpuratus. After a large settlement pulse, Rowley (1989) observed high densities of recently settled urchins in both a kelp bed and an adjacent barrens area. The density of these juveniles declined more rapidly in the kelp forest than in the barrens, suggesting that the lower numbers of adult urchins in kelp forests than barren grounds results from greater mortality in the kelp habitat (Rowley 1990). However, the generality of Rowley's conclusions is limited by the lack of replicate sites and the observation of a single settlement event.

Despite the influence of both mortality and movement, settlement can in some cases determine the distribution of recruits of mobile epifauna. O'Connor (1993) found that the distributions of the fiddler crabs Uca pugnax and Uca pugilator in a salt marsh in North Carolina were determined at settlement: the distributions of the 2 species differed within the marsh but the distribution of individuals of each species did not vary with age.
Early post-settlement mortality can influence the distribution of infauna in soft-bottom communities. In an intertidal community in South Carolina, Luckenbach (1984) compared sites with different densities of the polychaete Diopatra cuprea and showed that, although $D$. Cuprea tubes did not influence settlement of the bivalve Mulinia lateralis, they resulted in reduced numbers of bivalves in the smallest size class 1 mo later This reduction could have been due to emigration, but more likely resulted from interactions with other infauna (Luckenbach 1984). This conclusion was supported by a laboratory experiment (Luckenbach 1987 ) indicating reduced survival of recently metamorphosed $M$. lateralis in the presence of 2 polychaetes (Nereis succinea and Streblospio benedicti) which are common around $D$. cuprea tubes. Both settlement and post-settlement mortality appear to influence the distribution of male isopods (Paragnatha formica) in an English salt marsh (Upton 1987). Settlement is probably not indiscriminate as isopods were found only within a restricted vertical range and larval males were most abundant in core samples which contained adult males. However, juvenile males were disproportionately more abundant lower in the zone compared to adult males. Upton (1987) suggested that mortality of juveniles was greater lower in the zone where their molting chambers became waterlogged and anoxic Settling larvae may be able to avoid some agents of early juvenile mortality. For example, larvae of the spionid polychaete Pseudopolydophora kempi appear to avoid the polychaete Abarenicola pacifica, whose defecation may have negative impacts on small infauna (Woodin 1985). After sediment cores were outplanted in the field for $1 \mathrm{wk}$, densities of small spionids were greater in blank cores than in cores which contained an undamaged polychaete, a regenerating polychaete, or worm smell (worm removed before transplant to the field).

The vertical distribution in the deep sea of benthic invertebrates with planktonic larvae can be influenced by patterns of both settlement and early post-settlement mortality. In the Rockall Trough (2800 to $2900 \mathrm{~m}$ ) off the Hebrides Islands, UK, Gage \& Tyler (1981) found large numbers of juvenile ophuroids (Ophiocten gracilis), many of them corpses, in benthic samples collected in summer, but few in fall. The adult population of $O$. gracilis occurs from ca 600 to $1200 \mathrm{~m}$ depth on the slope surrounding the Trough and is most likely the source of this non-viable settlement in deep water (Gage \& Tyler 1981). In some cases, individuals which settle below the lower depth limit of the reproductive population survive. Mileikovsky (1961) argued, based on the horizontal distribution of larval stages in a series of plankton samples, that the deep-water population of the polychaete Euphrosyne borealis in the Norwegian 
Sea was a 'pseudopopulation', existing only because of the influx of larvae from depths above $400 \mathrm{~m}$.

\section{CONCLUSIONS AND DIRECTIONS FOR FUTURE RESEARCH}

Although our knowledge of the early post-settlement period is still limited, the number of studies addressing this topic is expanding rapidly. While the literature is currently biased towards a few groups of organisms (mainly barnacles and ascidians), the evidence to date suggests that early post-settlement mortality influences recruitment patterns of many different types of benthic marine invertebrates. The importance of events during this period arises from the very high rates of mortality of recent settlers (usually Type III survivorship, although mortality in the first few hours to days after settlement has only been observed for a few species) and the spatial and temporal variability of this mortality. Mortality patterns of early juveniles cannot necessarily be predicted from those of adults because vulnerability to different sources of mortality often varies with size (age). In many studies, spatial patterns of settlement or early post-settlement mortality were found to influence the distribution and abundance of adults, underscoring the importance of studying events which occur in the early benthic stage. Reviews of recruitment in other groups of marine organisms (e.g. benthic algae, Vadas et al. 1992; coral reef fish, Booth \& Brosnan) also have suggested the importance of high rates of early post-settlement mortality, but have not as yet established a clear link between early juvenile mortality and the distribution and abundance of recruits.

Factors which are known to cause mortality of recent settlers of benthic marine invertebrates include biological and physical disturbance, delay of metamorphosis, physiological stress, predation, and competition for food and space (Gosselin \& Qian 1997, this review). Predation has been the best-documented cause of early post-settlement mortality, particularly for mobile invertebrates, but most studies have focused on individuals several weeks to months after settlement. Similarly, mortality of juvenile fish on coral reefs is most often attributed to predation (Hixon 1991, Booth \& Brosnan 1995). Physical disturbance has received relatively little attention as a source of early post-settlement mortality of invertebrates, although wave action and water flow have been shown to cause mortality of macroalgal zygotes and germlings (for review see Vadas et al. 1992) and probably have the same effect on invertebrate settlers in the intertidal zone of rocky shores. Many causes of mortality of recently settled algae are similar to those reported for sessile inverte- brates, including grazing, canopy effects, presence of algal turf, and desiccation (reviewed by Vadas et al. 1992). Disease and parasitism are potential causes of early post-settlement mortality which have not yet been addressed, although the importance of these agents of mortality among older life history stages of marine invertebrates is well known (Kinne 1980). Problems arising at or before metamorphosis, such as developmental abnormalities (Rumrill 1990), complications during metamorphosis (Roegner 1991), or insufficient energy reserves (Gosselin \& Qian 1996), are other possible causes of early post-settlement mortality which should be investigated. Observations of recently settled individuals under benign conditions in laboratory aquaria may give some indication of the frequency of such problems and their influence on survivorship. Even at sublethal levels, disease, parasitism, developmental abnormalities, or poor physiological condition may increase mortality by increasing the susceptibility of recent settlers to predation or physical disturbance. Future studies of early post-settlement mortality should evaluate the influence of the various causes of mortality on patterns of abundance and distribution of recruits. Because of the lack of data on many of the causes of early post-settlement mortality, it is not presently possible to rank the various factors as selective pressures (Gosselin \& Qian 1997).

Early post-settlement mortality did not obscure the relationship between recruit and settler abundance in most studies of sessile invertebrates (almost all of barnacles), but this relationship appears to be more variable among mobile species. When recruit and settler density were related, mortality was either density independent or inversely density dependent. However, there is still insufficient data to support general conclusions about the conditions under which recruitment rate can be predicted from settlement rate. Studies examining the relationship between recruit and settler density under conditions of both density dependent and density independent mortality, and over a range of settler densities, are needed before conclusions can be drawn. Both early post-settlement mortality and settlement patterns have been shown to affect the distribution of recruits of sessile species at small spatial scales, but there is less evidence of the influence of mortality at larger scales. In addition to migration, early post-settlement mortality modifies the distribution of recruits of some mobile species. Differences among spatial scales in the importance of early postsettlement mortality may result from variation in the relative importance of different causes of mortality. Variation in the processes operating at different spatial scales has been documented for settlement. For example, active habitat selection becomes important at scales of centimetres to metres, but larvae tend to be 
passively deposited at large spatial scales (reviewed by Butman 1987). However, the scale dependence of differing processes influencing early post-settlement mortality has not yet been addressed.

Early post-settlement mortality probably exerts strong selective pressure on settlement patterns of both sessile and mobile invertebrates. A number of invertebrate species selectively settle in locations where early post-settlement mortality is low (Highsmith 1982, Young \& Chia 1984, Davis 1987, Hurlbut 1993). However, species with widely dispersing larvae may encounter different agents of mortality in different areas, resulting in 'fatal errors of set' (Strathmann et al. 1981). There may be tradeoffs between early post-settlement survivorship and adult or juvenile mortality (Keough 1986, Schubart et al. 1995). These tradeoffs can only be assessed in studies which examine the spatial and temporal variability of mortality of both settlers and older individuals. Genotype-specific post-settlement selection has been documented for mussel populations (for review see Cosling 1992), but most. studies have not isolated the stage at which selection occurs. Pedersen (1991) examined temporal variation in isozyme frequencies within Mytilus trossulus and found no evidence of early post-settlement selection. Further genetic studies contrasting settlers and recruits are necessary to determine whether postsettlement selection varies among different microhabitats or under different environmental conditions.

Studies of barnacles and ascidians have contributed much of our knowledge of early post-settlement mortality of benthic invertebrates. More information is now needed for other groups of benthic marine invertebrates, particularly mobile ones. Obtaining information about the fate of settlers of mobile species, which may undertake frequent and extensive movements or remain cryptic or buried in sediment, is much more difficult than mapping sessile organisms on exposed substrata. A combination of methods will probably prove most useful. Field experiments involving tethering and predator enclosures or exclosures can be used to identify causes of mortality (e.g. Table 3 ). Settlement rate on collectors or in passive settlement traps can provide an index of larval supply for comparison with subsequent censuses of recruits (e.g. collectors, Morgan et al. 1982, Peterson \& Summerson 1992, Forcucci et al. 1994, Herrnkind \& Butler 1994, Eggleston \& Armstrong 1995, Balch \& Scheibling in press; tube traps: Wilson 1990), although patterns and rates of settlement on artificial substrates may differ from those on natural substrata (e.g. Hunt \& Scheibling 1996). Laboratoryreared settlers can be transplanted to the field to examine mortality shortly after settlement when individuals from naturally settled cohorts are rare or difficult to detect (e.g. Keesing \& Halford 1992, Ray \&
Stoner 1995, Keesing et al. 1996). Tagging and marking methods using dye (Qian \& Chia 1994), microwire tags (Forcucci et al. 1994), nailpolish (Gosselin 1993), and plastic 'bee' tags (Barbeau et al. 1996) which enable researchers to follow the fate of individuals or cohorts of very small invertebrates have been developed. Time-lapse video photography may reveal early mortality events such as predation or dislodgment, particularly at times (e.g. at night or during storms) when direct observations in the field are difficult or impossible.

The relative importance of the early post-settlement period compared to other life history stages can only be determined in studies which examine several stages. Studies examining larval supply, settlement, and early post-settlement mortality (or recruitment) are necessary to provide information about the contribution of the various components of recruitment (e.g. Davis 1988a, Bertness et al. 1992, Eggleston \& Armstrong 1995). The importance of settlement and recruitment rates in regulating the dynamics of adult populations are best addressed in studies which follow individuals from settlement to adulthood (e.g. Davis 1988a, Raimondi 1990, Minchinton \& Scheibling 1991) or compare patterns of abundance and distribution of various age classes over a time series (e.g. Feller et al. 1992, Peterson \& Summerson 1992, Pile et al. 1996). Comparison of the distributions of different cohorts (settlers, recruits, and adults) at a single time also can provide valuable information (e.g. Grosberg 1982, Raimondi 1988a, Hurlbut 1991b, c, O'Connor 1993), but may confound temporal variation in abundance of cohorts with patterns of mortality. Matrix models can be used to explore the sensitivity of adult population size to changes in settlement rate and survivorship of various stages (e.g. Hughes 1990), although such models have seldom been applied to studies of marine invertebrates.

Finally, one of the major impediments to any synthesis of studies of recruitment in benthic marine invertebrates is the ambiguity in the operational definition of recruitment. While an operational definition of recruitment is appropriate to fisheries research (i.e. the size at which new individuals join the harvestable stock), there is no clear analogue in ecological studies of the marine benthos. The body size at which new individuals are recorded in invertebrate populations will be determined by the growth rate of early juveniles and (or) their behavioural and morphological adaptations for crypsis (perhaps by the persistence and eyesight of the observer as well!). Thus, the utility of the term recruitment according to its current usage in ecological studies of benthic marine invertebrates is questionable. The input of new individuals to a population can be quantified by censusing juveniles (= recruits) at a 
particular size or time after settlement without invoking a term. which may do more to obfuscate than clarify an ecological process. Recruitment may be more meaningful if it is used to quantify the addition of new individuals to the adult (breeding) population. This would require knowing the size (age) at sexual maturity for a given species, which can vary among populations and habitats but is easily measured in most cases. Recruitment as the number of individuals undergoing the transition to adulthood, a discrete biological event, would provide a more readily quantifiable and standardized measure of a demographic process than that given by current definitions of the term.

Acknowledgements. We thank 2 anonymous reviewers for helpful comments on the manuscript. H.L.H. was supported by a Natural Science and Engineering Research Council (NSERC) Postgraduate Award and an Izaak Walton Killam Memorial Scholarship from Dalhousie University.

\section{LITERATURE CITED}

Ahn IY, Lopez G, Malouf R (1993) Effects of the gem clam Gemma gemma on early post-settlement emigration, growth and survival of the hard clam Mercenaria mercenaria. Mar Ecol Prog Ser 99:61-70

Alexander SE, Roughgarden J (1996) Larval transport and population dynamics of intertidal barnacles: a coupled benthic/oceanic model. Ecol Monogr 66:259-275

Ambrose WG, Irlandi EA (1992) Helght of attachment on seagrass leads to trade-off between growth and survival in the bay scallop Argopecten irradians. Mar Ecol Prog Ser 90:45-51

Armonies W (1994) Turnover of postlarval bivalves in sediments of tidal flats in Königshafen (German Wadden Sea). Helgol Meeresunters 48:291-297

Aronson RB, Heck KL (1995) Tethering experiments and hypothesis testing in ecology. Mar Ecol Prog Ser 121 $307-309$

Baker SM, Mann R (1992) Effects of hypoxia and anoxia on larval settlement, juvenile growth, and juvenile survival of the oyster Crassostrea virginica. Biol Bull (Woods Hole) 182:265-269

Balch T, Scheibing RE (in press) Settlement and recruitment of echinoderms in kelp beds and sea urchin-dominated barren grounds in Nova Scotia. In: Mooi R, Telford M (eds) Proc 9th Int Echinoderm Conference. AA Balkema, Rotterdami

Barbeau MA, Hatcher BC, Scheibling RE, Hennigar AW, Taylor LH, Risk AC' (1996) Dynamics of juvenile sea scallop (Placopecten magellanirus) and their predators in bottom seeding trials in Lunenburg Bay, Nova Scotra. Can J Fish Aquat Sci $53: 2494 \cdots 2512$

Barbeau MA, Schnibling RE (1994a) Behavioral mechanisms of prey sıze selection by sea stars (Asterias vulgarıs Verrill) and crabs (Cancer irroratus Say) preying on juvenile sea scallops (Placopecten magellanicus (GMelin)). J Exp Mar Biol Ecol 180:103-136

Barbeau MA, Scheibling RE (1994b) Temperature effects on predation of juvenile sea scallops [Placopecten magellanicus (Gmelin)] by sea stars (Asterias vulgaris Verrill) and crabs (Cancer ıroratus Say). J Exp Mar Biol Ecol 182:27-47
Barbeau MA, Scheibling RE (1994c) Procedural effects of prey tethering experiments: predation of juvenile scallops by crabs and sea stars. Mar Ecol Prog Ser 111:305-310

Barbeau MA, Scheibling RE, Hatcher BG, Taylor LH, Hennigar AW (1994) Survival analysis of tethered juvenile sea scallops Placopecten magellanicus in field experiments. effects of predators, scallop size and density, site and season. Mar Ecol Prog Ser 115:243-256

Barkai A, Branch GM (1988) The influence of predation and substratal complexity on recruitment to settlement plates: a test of the theory of alternative states. J Exp Mar Biol Ecol 124:215-237

Barshaw DE, Able KW (1990) Tethering as a technique tor assessing predation rates in different habitats: an evaluation using juvenile lobsters Homarus americanus. Fish Bull (Wash DC) 88:415-417

Barshaw DE, Lavalli KL (1988) Predation upon postlural lobsters Homarus americanus by cunners Tautogolibrus adspersus and mud crabs Neopanope sayi on three different substrates: eelgrass, mud and rocks. Mar Ecol Prog Ser $48: 119-123$

Beal BF (1983) Predation of juveniles of the hard clam Mercenaria mercenaria (Linne) by the snapping shrimp A/pheus heterochaelis Say and Alpheus normanii Kingsley. J Shellfish Res $3: 1-9$

Bell SS, Coull BC (1.980) Experimental evidence for a model of Juvenile macrofauna-meiofauna interactions. In: Tenore KR, Coull BC: (eds) Marine benthic dynamics. University of South Carolind Press, Columbia, p 179-192

Bergeron P, Buurget E (1986) Shore topography and spatial partitioning of crevice refuges by sessile epibenthos in an ice disturbed environment. Mar Ecol Prog Ser 28:129-145

Bertness MD (1989) Intraspecific competition and facilitation in a northern acorn barnacle population. Ecology 70 $257-268$

Bertness MD, Gaines SD, Stephens EG, Yund PO (1992) Components of recruitment in populations of the acorn barnacle Semibalanus halanoides (Linnaeus). J Exp Mar Biol Ecol 156:199-215

Bertness MD, Gaines SD. Wahle RA (1996) Wind-driven settlement patterns in the acorn barnacle Semibalanus balanoides. Mar Ecol Prog Ser 137:103-110

Bingham BL (1992) Life historres in an epifaunal community: coupling of adult and larval processes. Ecology 73 : $2244-2259$

Bisker R. Castagna M (1987) Predation on single spat oysters Crassostrea virginica (Gmelin) by blue crabs Callmectes sapıdus Rathbun and mud crabs Panopeus herbstii MilneEdwards. J Shellfish Res 6:37-40

Booth DJ, Brosnan DM (1995) The role of recruitment dynamics in rocky shore and coral reel communities. In: Begon M, Fitter AH (eds) Advances in ecological research. Academic Press, San Diego, p 309-385

Bowman RS (1986) The blology of the limpet Patella vulgata $\mathrm{L}$. in the British Isles: spawning time as a factor determuning recruitment success. In: Moore PG, Seed R (eds) The ecology of rocky coasts. Columbia University Press, New York, p 178-193

Bowman RS, Lewis JR (1977) Annual fluctuations in the recruitment of Patella vulgata L. J Mar Biol Assoc UK 57 : $793-815$

Branch GM (1975) Ecology of Patella species from the Cape Peninsula, South Africa IV Desiccation. Mar Biol 32. $179-188$

Breen PA, Carolsfeld W, Yamanaka KL (1985) Social behaviour of Juvenile red sea urchins. Strongylocentrotus franciscanus (Agassiz). J Exp Mar Biol Ecol 92:45-61 
Brenchley GA (1981) Disturbance and community structure: an experimental study of bloturbation in marne soft-bottom environments. J Mar Res 39:767-790

Brown SD, Bert TM (1993) The effects of temperature and salinity on molting and survival of Menippe adina and $M$. mercenaria (Crustacea, Decapoda) postsettlement juvenules. Mar Ecol Prog Ser 99:41-49

Brown SD, Bert TM, Tweedale WA. Torres JJ, Lindberg WJ (1992) The effects of temperature and salinity on survival and development of early life history stage Florida stone crabs Menıppe mercenaria (Say). J Exp Mar Biol Ecol 157. 115. 136

Bushek D (1988) Settlement as a major determınant of intertidal orster and barnacle distributions along a horizontal gradient. J Exp Mar Biol Ecol 122:1-18

Buss LW (1979) Brvozoan overgrowth interactions - the interdependence of competition for space and food. Nature 281:475-477

Buss LW (1981) Group living, competition, and the evolution of cooperation in a sessile invertebrate. Science 213: 1012-1014

Butler MJ, Herrnkind WF (1997) A test of recrultment limitation and the potential for artificial enhancement of spiny lobster (Panulrus argus) populations in Florida. Can J Fish Aquat Sci 54:452-463

Butman CA (1987) Larval settlement of soft sediment invertebrates: the spatial scales of pattern explained by active habitat selection and the emerging role of hydrodynamical processes. Oceanogr Mar Bıl Annu Rev 25:113-165

Caffey HM (1982) No effect of naturally-occurring rock types on settlement or survival in the intertidal barnacle, Tesseropora rosea (Krauss). J Exp Mar Biol Ecol 63:119-132

Caffey HM (1985) Spatial and temporal variation in settlement and recrutment of intertidal barnacles. Ecol Monogr 55:313-332

Cameron RA, Schroeter SC $(1980)$ Sed urchin recruitment: effect of substrate selection on juvenile distribution. Mar Ecol Prog Ser 2:243-247

Carroll ML (1996) Barnacle population dynamics and recruitment regulation in southcentral Alaska. J Exp Mar Biol Ecol 199:285-302

Chen CP, Chen BY (1993) The effect of temperature-salinity combinations on survival and growth of juvenile Patiriella pseudoexigua (Echinodermata: Asteroidea). Mar Biol 115: $119-122$

Chittleborough RG. Phillips BF (1975) Fluctuatıons of yearclass strength and recruitment in the Western rock lobster Panulirus longipes (Milne-Edwards). Aust J Mar Freshwat Res 26:317-328

Connell JH (1961) Effects of competition, predation by Thais lapillus and other factors on natural populations of the barnacle Balanus balanoldes. Ecol Monogr 31:61-104

Connell JH (1970) A predator-prey system in the marine intertidal region. I. Balanus glandula and several proda. tory species of Thais. Ecol Monogr 40:49-78

Connell JH (1985) The consequences of variation in initial settlement vs. post-settlement mortality in rocky intertidal communties. J Exp Mar Biol Ecol 93:11-45

Creese RG (1982) Distribution and abundance of the acmaeid limpel, Patellorda latnstrigata, and its interaction with barnacles. Oecologra 52:85-96

Cummings VJ, Pridmore RD. Thrush SF (1996) Effect of the spionid polychaete Boccardia syrtis on the distribution and survival of juvenile Macoma Liliana (Bivalvia: Tellinacea). Mar Biol 126:91-98

Dalby JE, Young CM (1992) Role of early post-settlement mortality in setting the upper depth limit of ascidians in
Florida epifaunal communities. Mar Ecol Prog Ser 89: $221-228$

Davis AR (1987) Varlation in recruttment of the subtidal colonial ascidian Podoclavella cylindrica (Quoy \& Gaimard): the role of substratum choice and early survival. J Exp Mar Biol Ecol 106:57-71

Davis AR (1988a) Effects of variation in initial settlement on distribution and abundance of Podoclavella moluccensıs Sluiter. J IXxp Mar Biol Ecol 117:157-167

Davis AR (1988b) Colony regeneration following damage and size-dependent mortality in the Australian ascidian Podoclavella moluccensis Sluiter J Exp Mar Biol Ecol 123: $269-285$

Dayton PK (1971) Competition, disturbance, and community organization: the provision and subsequent utilization of space in a rocky intertidal community. Ecol Monogr 41: 331389

Dayton PK, Oliver JS (1980) An evaluation of experimental analyses of population and community patterns in benthic marıne environments. In: Tenore $\mathrm{KR}$, Coull $\mathrm{BC}$ (eds) Marine benthic dynamics. Unversity of South Carolina Press, Columbia, p 93-120

Deevey ES (1947) Life tables for natural populatıons of anlmals. Q Rev Biol 22:283-314

Denley EJ, Underwood AJ (1979) Experiments on factors influencing settlement, survival, and growth of two species of barnacles in New South Wales. J Exp Mar Biol Ecol 36:269-293

De Wolt P (1973) Ecological observations on the mechanisms of dispersal of barnacle larvae during planktonic life and settling. Neth J Sea Res 6:1-129

Dittel A, Epifanio CE, Natunewicz C (1996) Predation on mud crab megalopae, Panopeus herbstii H. Milne Edwards: effect of habitat complexity, predator species and postlarval densities. J Exp Mar Biol Ecol 198:191-202

Dungan ML (1985) Competition and the morphology, ecology and evolution of acorn barnacles: an experimental test. Paleobiology 11:165-173

Ebert TA, Russell MP (1988) Latitudinal variation in size structure of the west coast purple sea urchin: a correlation with headlands. Limnol Oceanogr 33:286-294

Ebert TA, Schroeter SC, Dixon JD, Kalvass P (1994) Settlement patterns of red and purple sea urchins (Strongylocentrotus franciscanus and S. purpuratus) in California, USA. Mar Ecol Prog Ser 111:41-52

Eckman JE (1987) The role of hydrodynamics in recruitment. growth, and survival of Argopecten irradians (L.) and Anomia simplex (D Orbigny) within eelgrass meadows. J Exp Mar Biol Ecol 106:165-191

Eggleston DB (1990) Foraging behavior of the blue crab, Callinectes sapidus, on juvenile oysters, Crassostrea virginica: effects of prey density and size. Bull Mar Scl 46:62-82

Eggleston DB. Armstrong DA (1995) Pre- and post-settlement. determinants of estuarme Dungeness crab recruitment. Ecol Monogr 65:193-216

Elmgren R, Ankar S, Marteleur B, Ejdung G (1986) Adult interference with postlarvae in soft sediments: the Pontoporela-Macoma example. Ecology 67:827-836

Fairweather PG (1988) Consequences of supply-side ecology: manipulating the recruitment of intertidal barnacles affects the intensity of predation upon them. Biol Bull (Woods Hole) 175:349-354

Farrant PA (1987) Population dynamics of the temperate Australıan soft coral Capnella gaboensis. Mar Biol 96:401-407

Farrell TM. Bracher D, Roughgarden J (1991) Cross-shelf transport causes recruitment to intertidal populations in central California. Limnol Oceanogr 36:279-288 
Feller RJ, Stancyk SE, Coull BC, Edwards DG (1992) Recruxtment of polychaetes and bivalves: long-term assessment of predictability in a soft-bottom habitat. Mar Ecol Prog Ser 87:227-238

Fernandez M, Armstrong D, Iribarne O (1993b) First cohort of young-of-the-year Dungeness crab, Cancer magister, reduces abundance of subsequent cohorts in intertidal shell habitat. Can J Fish Aquat Sci 50:2100-2105

Fernandez M, Iribarne O, Armstrong D (1993a) Habitat selec. tion by young-of-the-year Dungeness crab Cancer magister and predation risk in intertıdal habitats. Mar Ecol Prog Ser 92:171-177

Forcucci D. Butler MJ, Hunt JH (1994) Population dynamics of juvenile Carribean spiny lobster, Panulirus argus, in Florida Bay, Florida. Bull Mar Sc1 54:805-818

Foster BA (1971) On the determmants of the upper limit of intertidal distribution of barnacles (Crustacea: Cirripedia) J Anim Ecol 40:33-48

Fretter V, Manly R (1977) Algal associations of Tricolia pullus, Lacuna vincta and Cerithiopsis tubercularis (Ciastropoda) with special. reference to the settlement of their larvae. $J$ Mar Biol Assoc UK 57:999-1017

Gage JD, Tyler PA (1981) Non-viable seasonal settlement of larvae of the upper bathyal brittle star Ophiocten gracilis in the Rockall Trough Abyssal. Mar Biol 64:153-161

Gaines SD, Bertness MD (1992) Dispersal of juveniles and variable recruitment in sessile marine species. Nature 360 $579-580$

Gaines S, Brown S, Roughgarden J (1985) Spatial varlation in. larval concentrations as a cause of spatial variation in settlement of the barnacle, Balanus glandula. Oecologia 67 . $267-272$

Gaines S, Roughgarden J (1985) Larval settlement rate: a leading determinant of structure in an ecological community of the marine intertidal zone. Proc Nat Acad Sci USA $82: 3707-3711$

Garcìa-Esquivel Z, Bricelj VM (1993) Ontogenetic changes in microhabitat distribution of juvenile bay scallops, Argopecten irradians irradians (L.), in eelgrass beds, and their potential significance to recruitment. Biol Bull (Woods Hole) 185:42-55

Goodbody I (1963) The biology of Ascidia nigra (Savigny). Il The development and survival of young ascidians. Biol Bull (Woods Hole) 124:31-44

Goreau NI, Goreau TJ, Hayes RL (1981) Settling, survivorship and spatial aggregation in planulae and juveniles of the coral Portes porites (Pallas). Bull Mar Scl 31:424-435

Gosling EM (1992) Genetics of Mytilus. In: Gosling EM (ed) The mussel Mytulus: ecology, physiology, genetics and culture. Elsevier, Amsterdam, p 309-382

Gosselın LA (1993) A method for marking small juvenile gastropods. J Mar Biol Assoc UK 73:963-966

Gosselin LA, Chıd FS (1995a) Characterizing temperate rocky shores from the perspective of an early juvenile snail: the main threats to survival of newly hatched Nucella emarginata. Mar Biol 122:625-635

Gosselin LA, Chia FS (1995b) Distribution and dispersal of early juvenule snails: effectiveness of intertidal habitats as refuges and food sources. Mar Ecol Prog Ser 128:213-223

Gosselin LA, Chia FS (1996) Prey selection by inexperienced predators: do early juvenile snails maxımize net energy gains on their first attack? J Exp Mar Biol Ecol 199:45-58

Gosselin LA, Qian PY (1996) Early post-settlement mortality of an intertıdal barnacle: a critical period for survival. Mar Ecol Prog Ser 135:69-75

Gosselin LA, Qian PY (1997) Juvenile mortality in benthic marine invertebrates. Mar Ecol Prog Ser 146:265-282
Gotelli NJ (1987) Spatial and temporal patterns of reproduction, larval settlement, and recruitment of the compound ascidian Aplidium stellatum. Mar Biol 94:45-51

Grant WS (1977) High intertidal community organization on a rocky headland in Mame, USA. Mar Biol 44:15-25

Grosberg RK (1981) Competitive ability influences habitat choice un marine invertebrates. Nature 290:700-702

Grosberg RK (1982) Intertida! zonation of barnacles: the influence of planktonic zonation of larvae on the vertical distribution of adults. Ecology 63:894-899

Guillou J, Tartu C (1994) Post-larval and juvenile mortality in a population of the edible cockle Cerastoderma edule (L.) from northern Brittany. Neth J Sea Res 33:103-111

Gunther CP (1992) Settlement and recruitment of Mya artnara $\mathrm{L}$. in the Wadden sea. J Exp Mar Biol Ecol 159: $203-215$

Hall SJ, Raffaelli D, Turrell WR (1990) Predator-caging experiments in marine systems: a reexamination of their value. Am Nat 136:657-672

Hamel JF, Mercier A (1996) Early development, settlement, growth, and spatial distribution of the sea cucumber Cucumaria frondosa (Echinodermata: Holothuroidea). Can J Fish Aquat Sci 53:253-271

Harriott VJ (1983) Reproductive seasonality, settlement, and post-settlement mortality of Posillopora damicornis (Lin. naeus), at Lizard Island, Great Barrier Reef. Coral Reefs 2: $151-157$

Hatcher $B G$, Scheibling RE, Barbeau MA, Hennigar AW, Taylor LH, Windust AJ (1996) Dispersion and mortality of a population of sea scallop (Placopecten magellanicus) seeded in a tidal channel. Can J Fish Aquat Sci 53:38-54

Hatton $H$ (1938) Essais de bionomie explicative sur quelques espèces intercotidales d'algues et d'animaux. Ann Inst Oceanogr 17:241-348

Hawkins SJ (1983) Interactions of Patella and macroalgae with settling Semibalanus balanoides (L.). J Exp Mar Biol Ecol 71:55-72

Haywood MDE, Staples DJ (1993) Field estimates of growth and mortality of juvenile banana prawns (Penaeus merguiensis\}. Mar Biol 116:407-416

Herrnkind $\mathrm{WF}$, Butler MJ (1986) Factors regulating postlarval settlement and juvenile microhabitat use by spiny lobsters Panulirus argus. Mar Ecol Prog Ser 34:23-30

Herrnkind WF, Butler MJ (1994) Settlement of spiny lobster, Panulirus argus (Latteille, 1804) in Florida: pattern without predictability? Crustaceana 67:46-64

Highsmith RC (1982) Induced settlement and metamorphosis of sand dollar (Dendraster excentricus) larvae in predatorfree sites adult sand dollar beds. Ecology 63:329-337

Highsmith RC, Emlet RB (1986) Delayed metamorphosis: effect on growth and survival of juvenule sand dollars (Echinoidea: Clypeasteroida). Bull Mar Sci 39:347-361

$\mathrm{H}_{1 x o n} \mathrm{M}_{\mathrm{A}}$ (1991) Predation as a process structuring coral reef fish communities. In: Sale PF (ed) The ecology of fishes on coral reefs. Academic Press, Inc, San Diego, p 475-507

Hoffman DL (1989) Settlement and recruitment patterns of a pedunculate barnacle. Pollicipes polymerus Sowerby, off La Jolla, California. J Exp Mar Biol Ecol 125:83-98

Holland AF, Shaughnessy AT, Hiegel MH (1987) Long-term variation in mesohaline (hesapeake Bay macrobenthos: spatial and temporal patterns. Estuaries 10:227-245

Holm ER (1990) Effects of density-dependent mortality on the relationship between recruitment and larval settlement Mar Ecol Prog Ser 60:141-146

Howard RK (1988) Fish predators of the western rrck lobster (Panulirus cygnus George) in a nearshore nursery habutat. Aust J Mar Freshwat Res 39:307-316 
Hughes TP (1990) Recruitment limitation, mortality, and population regulation in open systems: a case study. Ecology $71: 12-20$

Hunt HL, Scheibling RE (1996) Physical and biological factors influencing mussel (Mytilus trossulus, M. edulis) settlement on a wave-exposed rocky shore. Mar Ecol Prog Ser 142:135-145

Hunt HL, Scheibling RE (in press) Effects of whelk (Nucella lapillus (L.)) predation on mussel (Mytilus trossulus (Gould), $M$ edulis (L.)) assemblages in tidepools and on emergent rock on a wave-exposed rocky shore in Nova Scotia, Canada. J Exp Mar Biol Ecol

Hurlbut CJ (1991a) Community recruitment: settlement and juvenile survival of seven co-occurring species of sessile marine invertebrates. Mar Biol 109:507-515

Hurlbut CJ (1991b) Larval substratum selection and postsettlement mortality as determinants of the distribution of two bryozoans. J Exp Mar Biol Ecol 147:103-119

Hurlbut CJ (1991c) The effects of larval abundance, settlement and juvenule mortality on the depth distribution of a colonial ascidian. J Exp Mar Bıol Ecol 150:183-202

Hurlbut CJ (1993) The adaptive value of larval behavior of a colonial ascidian. Mar Biol 115:253-262

Incze LS, Wable RA (1991) Recruitment from pelagic to early benthic phase in lobsters Homarus americanus. Mar Ecol Prog Ser 79:77-87

Jensen KT, Jensen JN (1985) The importance of some epibenthic predators on the density of juvenile benthic macrofauna in the Danish Wadden Sea. J Exp Mar Biol Ecol 89: $157-174$

Johns PM, Mann KH (1987) An experimental investigation of juvenile lobster habitat preference and mortality among habitats of varying structural complexity. $J$ Exp Mar Biol Ecol 109:275-285

Karlson RH, Levitan DR (1990) Recruitment-limitation in open populations of Diadema antularum: an evaluation. Oecologia 82:40-44

Keesing JK, Halford AR (1992) Field measurement of survival rates of juvenile Acanthaster planci: techniques and preliminary results. Mar Ecol Prog Ser 85:107-114

Keesing JK, Widermeyer WL, Okaji K. Halford AR, Hall KC, Cartwright CM (1996) Mortality rates of juvenile starfish Acanthaster planci and Nardoa spp. measured on the Great Barrier Reef, Australia and in Okinawa, Japan. Oceanol Acta 19:441-448

Kendall MA, Bedford ML (1987) Reproduction and recruitment of the barnacle Chthamalus montagui at Aberystwyth (mid-Wales). Mar Ecol Prog Ser 38:305-308

Kendall MA, Bowman RS, Williamson P, Lewis JR (1985) Annual variations in the recruitment of Semibalanus balanoides on the North Yorkshire Coast 1969-1981 J Mar Biol Assoc UK 65:1009-1030

Kenyon RA, Loneragan NR, Hughes JM (1995) Habitat type and light affect sheltering behaviour of juvenile tiger prawns (Penaeus esculentus Haswell) and success rates of their fish predators. J Exp Mar Biol Ecol 192:87-105

Keough MJ (1984) Dynamics of the epifauna of the bivalve Pinna bicolor: interactions among recruitment, predation, and competition. Ecology 65:677-688

Keough MJ (1986) The distribution of a bryozoan on seagrass blades: settlement, growth, and mortality. Ecology 67 : 846-857

Keough MJ, Chernoff H (1987) Dispersal and population variation in the bryozoan Bugula neritina. Ecology 68:199-210

Keough MJ, Downes BJ (1982) Recruitment of marine invertebrates: the role of active larval choices and early mortality. Oecologia 54:348-352
Keough MJ, Downes BJ (1986) Effects of settlement and postsettlement mortality on the distribution of the ascidian $T_{r 1}$ didemnun opacum. Mar Ecol Prog Ser 33:279-285

Kingsford MJ (1990) Linear oceanographic features: a focus for research on recruitment processes. Aust J Ecol 15: $391-401$

Kinne O (ed) (1980) Diseases of marine animals, Vol I. John Wiley \& Sons, Chichester

Laprise R, Blaber SJM (1992) Predation by Moses perch, Lutjanus russelli, and blue-spotted trevally, Caranx bucculentus, on juvenile brown tiger prawn, Penaeus esculentus effects of habitat structure and time of day. J Fish Biol 40 $627-635$

Lavalli KL, Barshaw DE (1986) Burrows protect postlarval lobsters Homarus americanus from predation by the non-burrowing cunner Tautogolabrus adspersus, but not from the burrowing mud crab Neopanope texani. Mar Ecol Prog Ser 32:13-16

Le Fèvre J, Bourget E (1991) Neustonic niche for cirripede larvae as a possible adaptation for long-range dispersal. Mar Ecol Prog Ser 74:185-194

Lewis JR, Bowman RS (1975) Local habitat-induced variations in the population dynamics of Patella vulgata L. J Exp Mar Biol Ecol 17:165-203

Luckenbach MW (1984) Settlement and early post-settlement survival in the recruitment of Mulima lateralis (Bivalvia) Mar Ecol Prog Ser 17:245-250

Luckenbach MW (1987) Effects of adult infauna on new recruits: implications for the role of biogenic refuges. J Exp Mar Biol Ecol 105:197-206

Magre EJ (1974) Ulva lactuca L. negatively affects Balanus balanoides (L.) (Cirripedia Thoracica) in tidepools. Crustaceana 27:231-235

Maldonado M, Young CM (1996) Effects of physical factors on larval behavior, settlement and recruitment of four tropical demosponges. Mar Ecol Prog Ser 138:169-180

Martel A, Chia FS (1991) Oviposition, larval abundance, in situ larval growth and recruitment of the herbivarous gastropod Lacuna vincta in kelp canopies in Barkley Sound Vancouver Island (British Columbia). Mar Biol 110 $237-247$

McCann LD, Levin LA (1989) Oligochaete influence on settlement, growth, and reproduction in a surface-deposit-feeding polychaete. J Exp Mar Biol Ecol 131:233-253

McCuiness KA, Davis AR (1989) Analysis and interpretation of the recruit-settler relationship. J Exp Mar Biol Ecol 134 $197-202$

McShane PE (1991) Density-dependent mortality of recruits of the abalone Haliotis rubra (Mollusca: Gastropoda). Mar Biol 110:385-389

McShane PE, Naylor JR (1995) Depth can affect post-settlement survival of Haliotis iris (Mollusca: Gastropoda). J Exp Mar Biol Ecol 187:1-12

Meadows PS (1969) Settlement, growth and competition in sublittoral populations of barnacles. Hydrobiologia 33: $65-93$

Menge BA (1976) Organization of the New England rocky intertidal community: role of predation, competition, and environmental heterogeneity. Ecol Monogr 46:355-393

Menge BA (1991) Relative importance of recruitment and other causes of variation in rocky intertidal community structure. J Exp Mar Biol Ecol 146:69-100

Menge BA, Berlow EL, Blanchette CA, Navarette SA, Yamada SB (1994) The keystone species concept: variation in interaction strength in a rocky intertidal habitat. Ecol Monogr 64:249-286

Menge BA. Farrell TM (1989) Community structure and inter- 
actions webs in shallow marine hard-bottom communities: tests of an environmental stress model. In: Begon M, Fitter $\mathrm{AH}$, Ford ED, MacFadigan A (eds) Advances in ecological research. Academic Press, London, p 189-262

Menge BA. Sutherland JP (1987) Community regulation: variation in disturbance, competition, and predation in relation to environmental stress and recruitment. Am Nat 130: $730-757$

Micheli F (1996) Predation intensity in estuarine soft-bottoms: between-habitat comparisons and experimental artifacts. Mar Ecol Prog Ser 141:295-302

Michener WK, Kenny PD (1991) Spatial and temporal patterns of Crassostrea virginica (Gmelin) recruitment: relationship to scale and substratum. J Exp Mar Biol Ecol 154:97-121

Milerkovsky SA (1961) Character and nature of deep-sea populations of eury bathic forms of invertebrates with pelagic larvae, taking as an example the polychaete Euphrosyne bortals Oersted 1843 from the North Atlantic. Okeanologiy'a 1:679-687 [in Russian, English translation in Deep Sea Res 9:531-537 (1962)l

Milerkovsky SA (1974) On predation of pelagic larvae and early juvenles of marme bottom invertebrates and their passing alive through their predators. Mar Biol 26 : 303-311

Miller KM, Carefoot TH (1989) The role of spatial and size refuges in the interaction between juvenile barnacles and grazing limpets. J Exp Mar Biol Ecol 134:157-174

Miller SE (1993) Larval period and its influence on post-larval life history: a comparison of lecithotrophy and facultative planktotrophy in the aeolid nudibranch Phestilla sibogae. Mar Biol 1.17:635-645

Mills A, Fish JD (1980) Effects of salinity and temperature on Corophium volutator and C. arenarnum (Crustacea: Amphipoda), with particular reference to distribution. Mar Biol 58:153-161

Minchinton TE, Scheibling RE (1991) The unfluence of larval supply and settlement on the population structure of barnacles. Ecology 72:1867-1879

Minchinton TE, Scheibling RE (1993d) Free space availability and larval substratum selection as determinants of barnacle population structure in a developing rocky intertidal community. Mar Ecol Prog Ser 95:233-244

Minchinton TE, Scheibling RE (1993b) Variations in sampling procedure and frequency affect estimates of recruitment of barnacles. Mar Ecol Prog Ser 99:83-88

Minello TJ, Zimmerman RJ, Martinez EX (1989) Mortality of young brown shnmp Penaeus aztecus in estuarne nurseries. Trans Am Fish Soc 118:693-708

Miron G, Boudreau B, Bourget E (1995) Use of larval supply in benthic ecology: testing correlations between larval supply and larval settlement. Mar Ecol Prog Ser 124:301-305

Möller P (1986) Physical and biological interactions regulating infaura in shallow bureal areas. Mar Ecol Prog Ser 30 : $33-47$

Moreno CA (1995) Macroalgae as a refuge from predation for recruits of the mussel Choromytilus chorus (Molina, 1782) in southern Chile. J Exp Mar Biol Ecol 191:181-193

Morgan GR, Philhips BF, Joll LM (1982) Stock and recruitment relationships in Panulirus cygnus, the commercial rock (spiny) lobster of Western Australia. Fish Bull (Wash DC) 80:475-486

Morgan SG, Zimmer-Faust RK, Heck KL, Coen LD (1996) Population regulation of blue crabs Callinectes sapidus in the northern Gulf of Mexico: postlarval supply. Mar Ecol Prog Ser 133:73-88

Muus K (1973) Settling, growth and mortality of young bivalves in the Oresund. Ophelia 12:79-116
O'Brien CJ (1994a) Population dynamics of juvenile tiger prawns Penaeus esculentus in south Queesland, Australia. Mar Ecol Prog Ser 104:247-256

O'Brien CJ (1994b) The effects of temperature and salinity on growth and survival of juvenile tiger prawns Penaeus esculentus (Haswell). J Exp Mar Biol Ecol 183:133-145

O'Connor NJ (1.993) Settlement and recruitment of the fiddler crabs Uca pugnax and U. pugilator in a North Carolina, USA, salt marsh. Mar Ecol Prog Ser 93:227-234

Ojeda FP, Dearborn JH (1991) Feeding ecology of benthic mobile predators: experimental analyses of theur influence in rocky subtidal communities of the Gulf of Maine. $J$ Exp Mar Biol Ecol 149:13-44

Olafsson EB (1989) Contrasting unfluences of suspensionfeeding and deposit-feeding populations of Macoma balthica on infaunal recrutment. Mar Ecol Prog Ser 55: $171-179$

Ólafsson EB, Peterson CH. Ambrose WG Jr (1994) Does recruitment limitation structure populations and communities of macro-invertebrates in marine soft sediments the relative significance of pre- and post-settlement processes. Annu Rev Oceanogr Mar Biol 32:65-109

Oliver JS, Oakden JM, Slattery PN (1982) Phoxoccphalid amphipod crustaceans as predators on larvae und juveniles in marine soft-bottom communities. Mar Ecol l'rog Ser 7:179-184

Oliver JS, Slatterly PN (1985) Effects of crustacean predators on species composition and population structure of softbodied infauna from McMurdo Sound, Antarctica. Ophelia $24: 155-175$

Olmi EJ, Lipcius RN (1991) Predation on postlarvae of the blue crab Callinectes sapidus Rathbun by sand shrimp Crangon septemspinosa Say and grass shrimp Palaemonetes pugio Holthus. J Exp Mar Biol Ecol 151:169-183

Olson RR (1983) Ascidian-Prochloron symbiosis: the role of larval photoadaptations in miday larval release and settlement. Biol Bull (Woads Hole) 165:221-240

Olson RR (1985) The consequences of short-distance larval dispersal in a sessile marne invertebrate. Ecology 66 $30-39$

Osman RW (1987) Interactions between the vermetid Serpulorbis squamigerus (Carpenter) and several species of encrusting bryozoans. J Exp Mar Biol Ecol 111:267-284

Osman RW, Whitlach RB (1995a) Predation on early ontogenetic life stages and its effect on recruitment mto a marine epifaunal community, Mar Ecol Prog Ser 117:111-126

Osman RW, Whitlach RB (1995b) The influence of resident adults on recruitment: a comparison to settlement J Exp Mar Biol Ecol 190:169-198

Osman RW, Whitlach RB, Malatesta RJ (1992) Potential role of micro-predators in determinıng recruitment into a marine Community. Mar Ecol Prog Ser 83:35-43

Osman RW, Whitiatch RB, Zajac RN 1 1989 ) Effects of resident species on recruitment into a community: larval settlement versus post-settlement mortality in the oyster Crassostrea virginica. Mar Ecol Prog Ser 54:61-73

Pawlik JR (1992) Chemical ecology of the settlement of benthic manne invertebrates. Oceanogr Mar Biol Annu Rev 30:273-335

Pechenik JA (1990) Delayed metamorphosis by larvae of benthic marine invertebrates: does it occur? Is there a price to pay? Ophelia 32:63-94

Pechenik JA, Cerulli TR (1991) Influence of delayed metamorphosis on survival, growth, and reproduction of the marine polychaete Capitella sp. I. J Exp Mar Biol Ecol 151 $17-27$

Pechenik JA, Eyster LS (1989) Influence of delayed metamor- 
phosis on the growth and metabolism of young Crepidula fornicata (Gastropoda) juveniles. Biol Bull (Woods Hole) 176:14-24

Pechenik JA, Rittschof D. Schmidt AR (1993) Influence of delayed metamorphosis on survival and growth of juvenile barnacles Balanus amphitrite. Mar Biol 115:287-294

Pedersen EM (1991) Population genetics of Mytilus from a developing intertidal community in Nova Scotia, Canada. MSc thesis, Dalhousie University, Halifax

Peterson CH (1977) Competitive organization of the softbottom macrobenthic communities of Southern Calıforna Jagoons. Mar Biol 43:343-359

Peterson CH (1979) Predation, competitive exclusion, and diversity in the soft-sediment benthic communities of estuaries and lagoons. In: Livingston RJ (ed) Ecological processes in coastal and marine systems. Plenum Press, New York, p 233-264

Peterson CH (1982) The importance of predation and intraand interspecific competition in the population biology of two infaunal suspension-feeding bivalves, Protothaca staminea and Chione undatella. Ecol Monogr 52:437-475

Peterson CH, Black R (1993) Experimental tests of the advantages and disadvantages of high density for two coexisting cockles in a Southern Ocean lagoon. J Anim Ecol 62: $614-633$

Peterson CH, Black R (1994) An experimentalıst's challenge: when artifacts of intervention interact with treatments. Mar Ecol Prog Ser 111:289-297

Peterson CH, Summerson HC (1992) Basın-scale coherence of population dynamics of an exploited marine invertebrate, the bay scallop: implications of recruitment limitation. Mar Ecol Prog Ser 90:257-272

Peterson CH, Summerson HC, Luettich RA (1996) Response of bay scallops to spawner transplants: a test of recruitment limitation. Mar Ecol Prog Ser 132:93-107

Petraitis PS (1983) Grazing patterns of the periwinkle and their effect on sessile intertıdal organisms. Ecology 64: $522-.533$

Petraitis PS (1990) Direct and indirect effects of predation, herbivory and surface rugosity on mussel recruitment. Oecologia 83:405-413

Petraltis PS (1991) Recruitment of the mussel Mytilus edulis L. on sheltered and exposed shores in Maine, USA. J Exp Mar Biol Ecol 147:65-80

Phillups BF (1990) Estimating the density and mortality of juvenile western rock lobsters (Panulurus cygnus) in nursery reefs. Can J Fish Aquat Sci 47:1330-1338

Pile AJ, Lipcius RN, van Montfrans J, Orth RJ (1996) Densitydependent settler-recruit-juvenile relationship in blue crabs. Ecol Monogr 66:277-300

Pohle DG, Bricelj VM, Garcia-Esquivel Z (1991) The eelgrass canopy: an above-bottom refuge from benthic predators for juvenile bay scallops Argopecten irradians. Mar Ecol Prog Ser 74:47-59

Prunce J (1995) Limited effects of the sea urchin Echinometra mathaei (de Blanville) on the recruitment of benthic algae and macroinvertebrates into intertidal rock platforms at Rottnest 1sland. Western Australia. J Exp Mar Bıol Ecol $186: 237-258$

Quan PY, Chia FS (1994) In situ measurement of recruitment, mortality, growth, and fecundity of Capilella sp. (Annelida: Polychaeta). Mar Ecol Prog Ser 111:53-62

Raimondi PT (1988a) Settlement cues and determination of the vertical limit of an intertidal barnacle. Ecology 69 $400-407$

Raimondi PT (1988b) Rock type affects settlement, recruitment, and zonation of the barnacle Chthamalus aniso- poma Pilsbury. J Exp Mar Biol Ecol 123:253-267

Raimondi PT (1990) Patterns, mechanısms, consequences of varability in settlement and recruitment of an intertidal barnacle. Ecol Monogr 60:283-309

Raimondi PT (1991) Settlement behavior of Chthamalus anisopoma larvae largely determines the adult distribution. Oecologia 85:349-360

Ray M. Stoner AW (1995) Growth, survivorship, and habitat choice in a newly settled seagrass gastropod, Strombus gigas. Mar Ecol Prog Ser 123:83-94

Relse K (1979) Moderate predation on melofauna by the macrobenthos of the Wadden Sea. Helgol Meeresunters 32: $453-465$

Robles C, Sherwood-Stephens R, Alvarado M (1995) Responses of a key intertidal predator to varying recruitment of its prey. Ecology 76:565-579

Roegner GC (1991) Temporal analysis of the relationship between settlers and early recruits of the oyster Crassostrea virginica (Gmelin). J Exp Mar Biol Ecol 151:57-69

Roegner GC, Mann R (1995) Early recruitment and growth of the American oyster Crassostrea virginica (Bivalva: Ostreidae) with respect to tidal zonation and season. Mar Ecol Prog Ser 117:91. 101

Ronn C, Bonsdorff E, Nelson WG (1988) Predation as a mechanism of interference withın infauna in shallow brackish water soft bottoms, experments with an infauna predator, Neress diversicolor O. F. Muller. J Exp Mar Biol Ecol 116: $143-157$

Roughgarden J, Gaines S, Possingham H (1988) Recruitment dynamics in complex life cycles. Science 241:1460-1466

Roughgarden J, Iwasa Y (1986) Dynamics of a metapopulation with space-limited subpopulations. Theor Popul Biol $29: 235-261$

Roughgarden J, Iwasa Y, Baxter C (1985) Demographic theory for an open marinu population with space-limited recruitment. Ecology 66:54-.67

Roughgarden J, Pennington JT, Stoner D. Alexander S, Miller $\mathrm{K}$ (1991) Collisions of upwelling fronts with the intertidal zone: the cause of recruitment pulses in barnacle populations of central California. Acta Oecol 12:35-51

Rowley RJ (1989) Settlement and recruitment of sea urchins (Strongylocentrotus spp.) in a sea-urchin barren ground and a kelp bed: are populations regulated by settlement or post-settlement processes? Mar Biol 100:485-494

Rowley RJ (1990) Newly settled sea urchıns in a kelp bed and urchin barren ground: a comparison of growth and mortalit y. Mar Ecol Prog Ser 62:229-240

Rumrill SS (1989) Population size-structure, juvenile growth, and breeding periodicity of the sea star Asterina miniata in Barkley Sound, Brttısh Columbia. Mar Ecol Prog Ser 56: $37-47$

Rumnll SS (1990) Natural mortality of marine invertebrate larvae. Ophelia 32:163-198

Safriel UN, Erez N, Keasar T (1994) How do limpets mantain barnacle-free submerged artificıal surfaces? Bull Mar Sci $54: 17-23$

Sammarco PW (1980) Diadema and its relationship to coral spat mortality: grazing, competition, and biological disturbance. J Exp Mar Biol Ecol 45:245-272

Sammarco PW, Andrews JC (1989) The Helix experiment: differential localized dispersal and recrutment patterns in Great Barner Reef corals. Limnol Oreonogr 34:896-912

Sanchez-Salazar ME, Griffiths CL, Seed R (1987) The effect of size and temperature on the predation of cockles Cerastoderma edule (L.) by the shore crab Carcinus maenus (L.).J Exp Mar Biol Ecol 111:181-193

Sandt VJ, Stoner AW (1993) Ontogenetic shift in habitat by 
early juvenile queen conch, Strombus gigas: patterns and potential mechanisms. Fish Bull (Wash DC) 91:516-525

Sarver DJ (1979) Recruitment and juvenile survival in the sea hare Aplysia juliana (Gastropoda: Opistobranchia). Mar Biol 54:353-361

Scheibling RE (1996) The role of predation in regulating sea urchin populations in eastern Canada. Oceanol Acta 19 $421-430$

Scheibling RE, Hamm J (1991) Interactions between sea urchins (Strongylocentrotus droebachiensis) and their predators in field and laboratory experiments. Mar Biol 110:105-116

Scheibling RE. Hatcher BG (1997) Microhabitat refuges and risk of predation for two species of trochid gastropod (Trochus histrio and Tectus pyramis) at the Houtman Abrolhos, Western Australia. In: Wells FE (ed) The marine flora and fauna of the Houtman Abrolhos Islands, Western Australia. Western Australian Museum, Perth, p 159-176

Schubart CD, Basch LV, Miyasato G (1995) Recruitment of Balanus glandula Darwin (Crustacea: Cirripedia) into empty barnacle tests and its ecological consequences. $J$ Exp Mar Bıol Ecol 186:143-181

Sebens KP (1983) The larval and juvenile ecology of the temperate octocoral Alcyonium siderium Verrill. II. Fecundity, survival, and juvenile growth. J Exp Mar Biol Ecol 72: $263-285$

Seed R, Wood V (1994) Recruitment and mortality of Alcyonidium hirsutum (Fleming) and Flustrellidra hispida (Fabricius) (Bryozoa: Ctenostomata) within a Fucus serratus L. community. Cah Biol Mar 35:305-326

Shanks AL, Wright WG (1987) Internal-wave-mediated transport of cyprids, megalopae, and gammands and correlated longshore differences in the settlement rate of intertidal barnacles. J Exp Mar Biol Ecol 114:1-13

Singletary RL, Shadlou R (1983) Balanus balanoides in tidepools: a question of maladaptation? Crustaceana 45:53-71

Smith KN, Herrnkund WR (1992) Predation on early juvenile spiny lobsters Panulirus argus (Latreille): influence of sizs. and shelter. J Exp Mar Biol Ecol 157:3-18

Staples DJ, Hedles DS (1991) Temperature and salinity optima for growth and survival of juvenile banana prawns Penaeus merguiensis. J Exp Mar Biol Ecol 154:251-274

Stephens EG, Bertness MD (1991) Mussel facilitation of barnacle survival in a sheltered bay habitat. J Exp Mar Biol Ecol 145:33-48

Stimson J (1970) Territorial behavior of the owl limpet, Lottia gigantea. Ecology 51:113-118

Stoner DS (1990) Recruitment of a tropical colonial ascidian: relative importance of pre-settlement vs. post-settlement processes. Ecology 71:1682-1690

Stoner DS (1992) Vertical distribution of a colonial ascidian on a coral reef: the roles of larval dispersal and life-history variation. Am Nat 139:802-824

Strathmann RR, Branscomb ES (1979) Adequacy of cues to favorable sites used by settling larvae of two intertidal barnacles. In: Stancyk SE (ed) Reproductive ecology of marine invertebrates. University of South Carolina, Columbia, p 77-89

Strathmann RR, Branscomb ES, Vedder K (1981) Fatal errors in set as a cost of dispersal and the influence of intertidal flora on set of barnacles. Oecologia 48:13-18

Summerson HC, Peterson CH (1990) Recruitment failure of the bay scallop, Argopecten irradians concentricus, during the first red tide, Ptychodiscus brevis, outbreak recorded in North Carolina. Estuaries 13:322-331

Sutherland JP (1987) Recruitment Immıtation in a tropical intertidal barnacle: Tetraclita panamensis (Pilsbry) on the
Pacific coast of Costa Rica. J Exp Mar Biol Ecol 11.3: $267-282$

Sutherland JP (1990) Recruitment regulates demographic variation in a tropical intertidal harnacle. Ecology 71 $955-972$

Sutherland JP, Ortega S (1986) Competition conditional on recruitment and temporary escape from predators on a tropical rocky shore. J Exp Mar Biol Ecol 95:155-166

Tan WH (1975) The effects of exposure and crawling behaviour on the survival of recently settled green mussels (Mytilus viridis L.). Aquaculture 6:357-368

Tegner MJ. Dayton PK (1977) Sea urchin recrultment patterns and implications of commercral fishing. Science 196: $324-326$

Thorson $G$ (1966) Some factors influencing the recruitment and establishment of marine benthic communities. Neth $J$ Sea Res 3:267-293

Thrush SF, Hewitt JE, Pridmore RD, Cummings VJ (1996) Adult/juvenile interactions of infaunal bivalves: contrasting outcomes in different habitats. Mar Ecol Prog Ser 132 $83-92$

Turner SJ, Todd CD (1991) The effects of Gibbula cineraria (L.), Nucella lapillus (L.) and Asterias rubens L. on developing epifaunal assemblages. J Exp Mar Biol Ecol 154 $191-213$

Underwood AJ, Denley EJ, Moran MJ (1983) Experimental analyses of the structure and dynamics of mid-shore rocky intertidal communities in New South Wales. Oecologia 56: $202-219$

Upton NPD (1987) Gregarious larval settlement within a restricted intertidal zone and sex differences in subsequent mortality in the polygy nous saltmarsh isopod Paragnathia formica (Crustacea: Isopoda). J Mar Biol Assoc UK $67: 663-678$

Vadas RL, Johnson S, Norton TA (1992) Recruitment and mortality of early post-settlement stages of benthic algae. Br Phycol J 27:331-351

Vance DJ, Haywood MDE, Heales DS, Staples DJ (1996) Seasonal and annual variation in abundance of postlarval and juvenile grooved tiger prawns Penaeus semisulcatus and environmental variation in the Embley River, Australia: a six year study. Mar Ecol Prog Ser 135:43-55

van Duyl FC, Bak RPM, Sybesma J (1981) The ecology of the tropical compound ascidian Trididemnum solidum 1 . Reproductıve strategy and larval behaviour. Mar Ecol Prog Ser 6:35-42

Vermeij G.J (1972) Intraspecific shore-level size gradients in intertidal molluscs. Ecology 53:693-700

Wahle: RA, Steneck RS (1991) Recrutment habitats and nursery grounds of the American lobster Homarus americanus: a demographic bottleneck? Mar Ecol Prog Ser 69:231-243

Wahle RA, Steneck RS (1992) Habitat restrictions in early benthic life: experments on habitat selection and in situ predation with the American lobster. J Exp Mar Biol Ecol 157:91-114

Walters LJ (1992) Field settlement locations on subtidal marme hard substrata: is active larval exploration involved? Limnol Oceanogr 37:1101-1107

Walters LJ, Wethey DS (1996) Settlement and early post-settlement survival of sessile marine invertebrates on topographically complex surfaces: the importance of refuge dimensions and adult morphology. Mar Ecol Prog Ser 137 $161-171$

Watts A, Scheibling RE, Marsh AG, McCluntock JB (1983) Induction of aberrant ray numbers in Echinaster $\mathrm{sp}$. (Echinodermata: Asteroidea) by high salınity. Florida Scl $46: 125-128$ 
Watzin MC (1983) The effects of meiofauna on settling macrofauna: mesofauna may structure macrofaunal communities. Oecologia 59:163-166

Watzin MC (1986) Larval settlement into marine soft-sediment systems: interactions with the meiofauna. J Exp Mar Biol Ecol 98:65-113

Weinberg JR (1984) Interactions between functional groups in soft-substrata: do species differences matter? J Exp Mar Biol Ecol 80:11-28

Weiss CM (1948) Seasonal and annual variations in the attachment and survival of barnacle cyprids. Biol Bull (Woods Hole) 94:236-243

Wethey DS (1984) Sun and shade mediate competition in the barnacles Chthamalus and Semibalanus: a field experiment. Biol Bull (Woods Hole) 167:176-185

Wethey DS (1986) Local and regional variation in settlement and survival in the littoral barnacle Semibalanus balanoides (L.): patterns and consequences. In: Moore PG. Seed R (eds) The ecology of rocky coasts. Columbia University Press, New York, p $194-202$

Wiedemeyer WL (1994) Biology of small juveniles of the tropical holothurian Actinopyga echinites: growth, mortality, and habitat preferences. Mar Biol 120:81-93

Williams JG (1980a) Growth and survival in newly settled spat of the Manila clam, Tapes japonica. Fish Bull (Wash DC) $77: 891-900$

Williams JG (1980b) The influence of adults on the settlement of spal of the clam, Tapes japonica. J Mar Res 38:729-741

Wilson IS (1990) Temporal and spatial patterns of settlement: a field study of molluscs in Bogue Sound, North Carolina. J Exp Mir Biol Ecol 139:201-220

Wilson KA, Able KW, Heck KL (1990) Predation rates on juvenile blue crabs in estuarine nursery habitats: evidence for the importance of macroalgae (Ulva lactuca). Mar Ecol Prog Ser 58:243-251

Wilson KA, Heck KL, Able KW (1987) Juvenule blue crab, Callinectes sapidus, survival: an evaluation of eelgrass, Zostera marina, as refuge. Fjsh Bull (Wash DC) 85:53-58

Wilson WHW (1981) Sediment-mediated interactions in a densely populated infaunal assemblage: the effects of the polychaete Abarenicola pacifica. J Mar Res 39:735-748

Wing SR, Botslord LW, Largier JL, Morgan LE (1995) Spatial structure of relaxation events and crab settlement in the northern California upwelling system. Mar Ecol Prog Ser 128:199-211

This review was presented by Charles Peterson (Senior Editorial Advisor), Morehead City, North Carolina, USA
Woodin SA (1976) Adult-larval interactions in dense infaunal assemblages: patterns of abundance. J Mar Res 34 $25-41$

Woodın SA (1985) Effects of defecation by arenicolid polychaete adults on spionid polychaete juveniles in field experiments: selectuve settlement or differential mortality. J Exp Mar Biol Ecol 87:119-132

Worcester SE (1994) Adult rafting versus larval swimming: dispersal and recruitment of a botryllid ascidian on eelgrass. Mar Biol 121:309-317

Yoshioka PM (1986) Chaos and recruitment in the bryozoan, Membranipora membranacea. Bull Mar Scl 39:408-417

Young BL (1991) Spartina axil zones: preferred settlement sites of barnacles. J Exp Mar Bıol Ecol 151:71-82

Young CM, Braithwaite LF (1980) Larval behavior and postsettling morphology in the ascidian, Chelyosoma productum Stimpson. J Exp Mar Biol Ecol 42:157-169

Young CM, Chia FS (1981) Laboratory evidence for delay of larval settlement in response to a dominant competitor. Int $\mathrm{J}$ Invertebr Reprod 3:221-226

Young CM, Chia FS (1982) Factors controlling spatial distribution of the sea cucumber Psolus chitonoides: settling and post-settling behavior. Mar Bıol 69:195-205

Young CM, Chia FS (1984) Microhabitat-associated variability in survival and growth of subtidal solitary ascidians during the first 21 days after settlement. Mar Biol 81 . $61-68$

Yund PO, Cunningham CW, Buss LW (1987) Recruitment and postrecruitment interactions in a colonial hydroid. Ecology 68:971-982

Zajac RN, Whitlatch RB, Osman RW (1989) Effects of interspecific density and food supply on survivorship and growth of newly settled benthos. Mar Ecol Prog Ser 56 $12 ; \cdot 132$

Zamorano JH, Moreno CA, Duarte WE (1995) Post-settlement mortality in Phragmatopoma virgini (Polychaeta: Sabellariidae) at the Mehuin Marıne Reserve, Chile. Mar Ecol Prog Ser 127:149-155

Zimmer-Faust RK, Fielder DR, Heck KL, Coen LD, Morgan SG (1994) Effects of tethering on predatory escape by juvenile blue crabs. Mar Ecol Prog Ser 111:299-303

Zobrist EC, Coull BC (1994) Meiofaunal effects on growth and survivorship of the polychaete Streblosplo benedicti Webster and the bivalve Mercenaria mercenaria (L.). J Exp Mar Biol Ecol 175:167-179

Manuscript received: October 11, 1996

Revised version accepted: June 24, 1997 